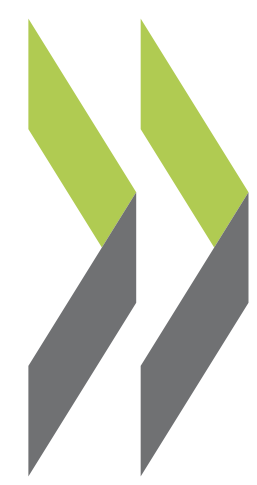

OECD Economics Department Working Papers No. 1542

Calibrating GDP fan charts using probit models with
a comparison to the approaches of the Bank of England and Riksbank David Turner, Thomas Chalaux 


\section{CALIBRATING GDP FAN CHARTS USING PROBIT MODELS WITH A COMPARISON TO THE APPROACHES OF THE BANK OF ENGLAND AND RIKSBANK}

\section{ECONOMICS DEPARTMENT WORKING PAPERS No. 1542}

\section{By David Turner and Thomas Chalaux}

OECD Working Papers should not be reported as representing the official views of the OECD or of its member countries. The opinions expressed and arguments employed are those of the author(s).

Authorised for publication by Alain de Serres Deputy Director, Policy Studies Branch, Economics Department.

All Economics Department Working Papers are available at www.oecd.org/eco/workingpapers.

JT03443908 
OECD Working Papers should not be reported as representing the official views of the OECD or of its member countries. The opinions expressed and arguments employed are those of the author(s).

Working Papers describe preliminary results or research in progress by the authors and are published to stimulate discussion on a broad range of issues on which the OECD works.

Comments on Working Papers are welcomed, and may be sent to OECD Economics Department, 2 rue André Pascal, 75775 Paris Cedex 16, France, or by e-mail to eco.contact@oecd.org.

All Economics Department Working Papers are available at www.oecd.org/eco/workingpapers.

On 3 May 2018, the OECD Council invited Lithuania to become a Member. At the time of publication the deposit of Lithuania's instrument of accession to the OECD Convention was pending and therefore Lithuania does not appear in the list of OECD Members and is not included in the OECD zone aggregates.

On 25 May 2018, the OECD Council invited Colombia to become a Member. At the time of publication the deposit of Colombia's instrument of accession to the OECD Convention was pending and therefore Colombia does not appear in the list of OECD Members and is not included in the OECD zone aggregates.

This document and any map included herein are without prejudice to the status of or sovereignty over any territory, to the delimitation of international frontiers and boundaries and to the name of any territory, city or area.

The statistical data for Israel are supplied by and under the responsibility of the relevant Israeli authorities. The use of such data by the OECD is without prejudice to the status of the Golan Heights, East Jerusalem and Israeli settlements in the West Bank under the terms of international law.

Latvia was not an OECD member at the time of preparation of this paper. Accordingly, Latvia is not included in the list of OECD countries and is not included in the area totals.

\section{(c) OECD (2019)}

You can copy, download or print OECD content for your own use, and you can include excerpts from OECD publications, databases and multimedia products in your own documents, presentations, blogs, websites and teaching materials, provided that suitable acknowledgment of OECD as source and copyright owner is given. All requests for commercial use and translation rights should be submitted to rights@oecd.org 


\section{Abstract/Résumé \\ Calibrating GDP Fan Charts Using Probit Models with a Comparison to the Approaches of the Bank of England and Riksbank}

Fan charts were pioneered by the Bank of England and Riksbank and provide a visually appealing means to convey the uncertainty surrounding a forecast. This paper describes a method for parameterising fan charts around GDP growth forecasts by which the degree of uncertainty is based on past forecast errors, but the skew is derived from a probit modelbased assessment of the probability of a future downturn. The probit-based fan charts clearly out-perform the Bank of England and Riksbank approaches when applied to forecasts made immediately preceding the Global Financial Crisis. These examples also highlight weaknesses with the Bank of England and Riksbank approaches.

- The Riksbank approach implicitly assumes that forecast errors are normally distributed, but over a long track record this is unlikely to be the case because forecasters are generally poor at predicting downturns, which leads to bias and skew in the pattern of forecast errors. Thus, the Riksbank fan chart is neither an accurate representation of past forecast errors, nor is it a reflection of the risk assessment underlying the forecast.

- The Bank of England approach relies heavily on the judgment of the members of the Monetary Policy Committee to assess risks. However, even when they have correctly foreseen the nature of future risks, the quantitative translation of these risks into the fan chart skew has been too timid. Perhaps one reason for this is that the fan chart prediction intervals based on historical forecast errors already appear quite wide so that inflating them by adding skew may appear embarrassing (at least ex ante).

The approach advocated in this paper addresses these weaknesses by recognising that forecast errors are not symmetrical: firstly, this leads to more compressed prediction intervals in the upper part of the fan chart (representing the possibility of under-prediction); and secondly, using the large forecast errors from past downturns to calibrate downward skew clearly supports a more bold approach when there is a risk of a downturn. A weakness of the probit model-based approach is that it will not predict atypical downturns. For example, in the current conjuncture it would not pick up risks associated with a 'no deal' Brexit or a global trade war. However, a downturn triggered by atypical events may be more severe if risk factors describing a typical business-financial cycle are also high.

JEL Classification: E58, E17, E65, E66, E01.

Keywords: fan charts, economic forecasts, uncertainty, risk, downturn, recession. 


\section{Calibrer les graphiques en éventail du PIB à l'aide de modèles probits, en comparant avec les approches de la Bank of England et de la Riksbank}

La Bank of England et la Riksbank ont été les premières à créer des graphiques en éventail en tant que moyens visuellement attrayants pour exprimer l'incertitude entourant les prévisions. Ce document décrit une méthode de paramétrage des graphiques en éventail autour des prévisions de croissance du PIB, selon laquelle le degré d'incertitude est basé sur les erreurs de prévision passées, mais le biais est dérivé d'une évaluation de la probabilité d'un futur ralentissement basée sur un modèle probit. Les graphiques en éventail basés sur les probits surpassent clairement les approches de la Bank of England et de la Riksbank quand ils sont appliqués aux prévisions établies immédiatement avant la crise financière mondiale. Ces exemples mettent également en évidence les faiblesses des approches de la Bank of England et de la Riksbank.

- L'approche de la Riksbank suppose implicitement que les erreurs de prévision sont normalement distribuées, mais il est peu probable que cela se produise, car les prévisionnistes sont généralement médiocres pour prévoir les récessions, ce qui entraîne un biais et une asymétrie dans le schéma des erreurs de prévision. Ainsi, les graphiques en éventail de la Riksbank ne sont ni une représentation précise des erreurs de prévision passées, ni un reflet de l'évaluation des risques sous-jacents à la prévision.

- L'approche de la Bank of England repose largement sur le jugement des membres du Comité de politique monétaire pour évaluer les risques. Cependant, même lorsqu'ils ont correctement prévu la nature des risques futurs, la traduction quantitative de ces risques dans les graphiques en éventail est trop timide. Cela s'explique peut-être par le fait que les intervalles de prédiction des graphiques en éventail basés sur des erreurs de prévision historiques semblent déjà assez larges, de sorte que les gonfler en ajoutant un biais peut sembler embarrassant (au moins ex ante).

L'approche préconisée dans le présent document aborde cette question en reconnaissant que les erreurs de prévision ne sont pas symétriques: premièrement, cela conduit à des intervalles de prévision plus compressés dans la partie supérieure des graphiques en éventail (représentant la possibilité d'une sous-prédiction); et deuxièmement, l'utilisation des grandes erreurs de prévision des récessions passées pour calibrer le biais favorise clairement une approche plus audacieuse. Une des faiblesses de cette approche fondée sur des modèles probit est qu'elle ne permet pas de prédire les ralentissements atypiques. Par exemple, dans la conjoncture actuelle, il ne prendrait pas en compte les risques associés à un Brexit «dur» ou à une guerre commerciale mondiale. Toutefois, une récession déclenchée par des événements atypiques peut être encore plus grave si des facteurs de risque plus typiques sont également élevés.

Codes JEL: E58, E17, E65, E66, E01.

Mots clés : graphiques en éventail, prévisions économiques, incertitude, risque, crise, récession. 


\section{Table of contents}

\section{CALIBRATING GDP FAN CHARTS USING PROBIT MODELS WITH A COMPARISON TO THE APPROACHES OF THE BANK OF ENGLAND AND RIKSBANK............................ 6}

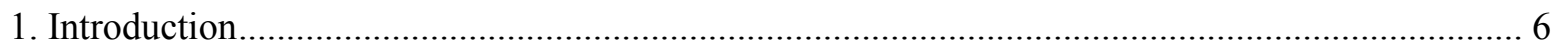

2. The Bank of England and Riksbank approaches to parameterising fan charts .............................. 9

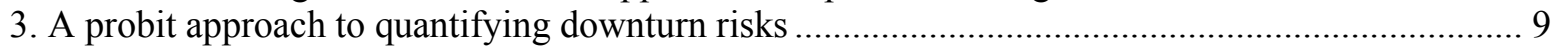

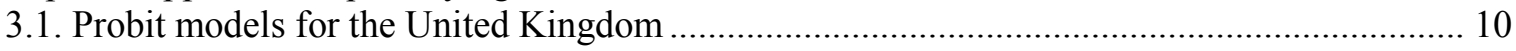

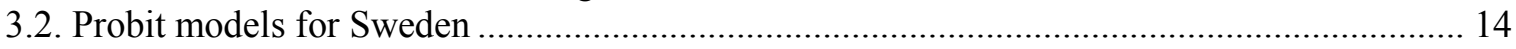

4. Linking quarterly probit probabilities to annual downturn risks .................................................. 16

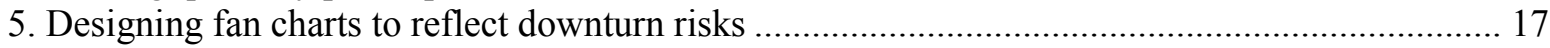

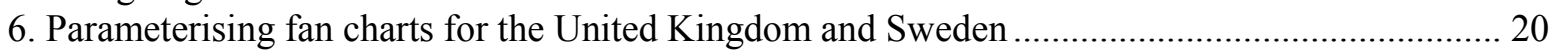

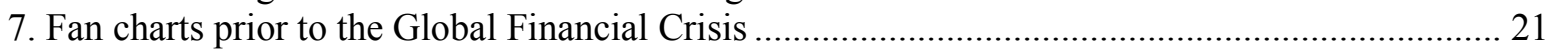

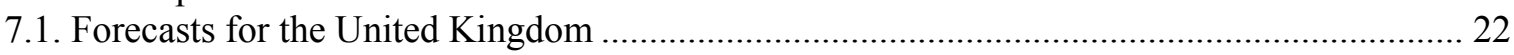

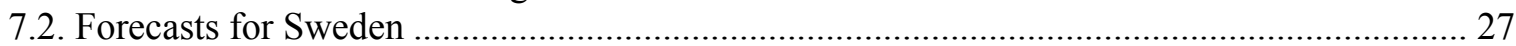

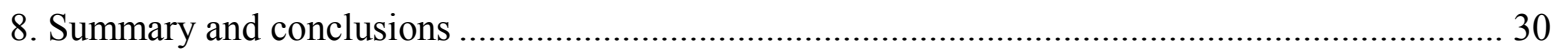

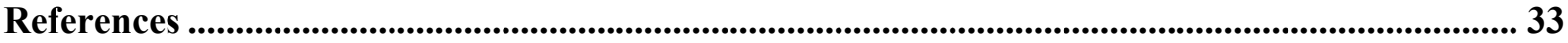

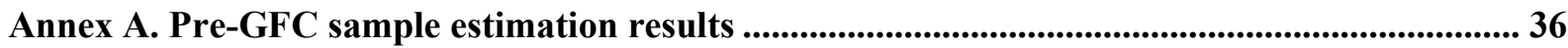

\section{Tables}

Table 1. Probit regressions explaining downturns in the United Kingdom........................................ 13

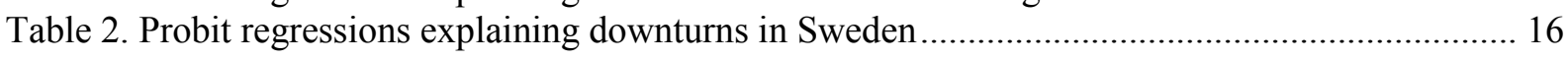

Table 3. Regressions of forecast errors for the United Kingdom on downturn probabilities ................ 21

Table 4. Regressions of forecast errors for Sweden on downturn probabilities .................................... 21

\section{Figures}

Figure 1. OECD GDP growth forecast errors for the United Kingdom and Sweden ............................. 8

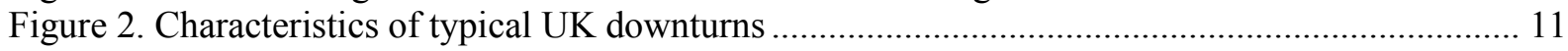

Figure 3. Downturn predictions of the probit models for the United Kingdom ........................... 12 


\title{
CALIBRATING GDP FAN CHARTS USING PROBIT MODELS WITH A COMPARISON TO THE APPROACHES OF THE BANK OF ENGLAND AND RIKSBANK
}

\author{
By David Turner and Thomas Chalaux ${ }^{1}$
}

\section{Introduction}

1. The Bank of England and the Riksbank pioneered the use of fan charts in the late 1990 s as a means of conveying uncertainty surrounding macroeconomic forecasts, with this practice since spreading to other central banks and macroeconomic forecasters. The present paper focusses on the design of fan charts around GDP growth forecasts. It applies a method by which the degree of uncertainty (the overall spread of the fan chart) is based on past forecast errors, but the skew (reflecting whether risks are tilted to the downside) is derived from a model-based assessment of the probability of a future downturn due to risk factors describing a typical business-financial cycle. This method is then compared with the approaches of the Bank of England and Riksbank.

2. Fan charts are easily interpretable visual devices that serve to emphasise the uncertainty surrounding a forecast and so downplay the point forecasts, which would seem appropriate given the relatively poor track record of most macroeconomic forecasters, especially at horizons beyond the current year. For the same reason, it would seem appropriate that the dispersion underlying a fan chart is in some way grounded on historical forecasting performance, so that forecast uncertainty can be assessed against past forecast errors.

3. Using the historical forecast performance as the basis to parameterise fan charts for GDP growth, however, runs into a problem that over a long track record forecast errors tend to be biased towards over-prediction because macroeconomic forecasters appear to exhibit a serial failure to predict future downturns, for which the largest forecast errors are usually made. The abysmal track record of macroeconomic forecasters in predicting future recessions is borne out by numerous surveys of different forecasters over various periods for many countries (for example: Lougani, 2001; Abreu, 2011; Fildes and Stekler, 2002; Pain and Lewis, 2014). OECD forecasts published in the OECD Economic Outlook are typical: since 1991, less than 10\% of forecasts for OECD countries published in May/June correctly identified a recession in the following year (Turner et al., 2018). ${ }^{2}$ OECD forecasts

\footnotetext{
${ }^{1}$ The authors are member of the OECD Economics Department. Particular thanks are due to Jeroen Meyer for constructing a consistent historical database of forecast errors, without which this work would not have been possible. Thanks also to Hermes Morgavi, Nikki Kergozou (Paris School of Economics) and Christophe Andre, Martine Durand and Pierre-Alain Pionnier for comments, ideas and inspirational discussions as well as to Veronica Humi for editorial support.

2. The IMF has a similarly poor performance as illustrated in a chart published in a recent Financial Times article entitled "IMF shows poor track record in forecasting recessions" (Romei and Fray, 2018), which shows that "Over the last 27 years, the IMF has predicted every October that an average of five economies will contract the following year. In practice, an average of 26 have contracted".
} 
are also typical in being biased towards over-prediction, at least for forecasts beyond the current year, with the largest outliers corresponding to downturn periods, so that the distribution of forecast errors cannot be characterised by a normal distribution for forecast horizons beyond the current year (see Figure 1 for evidence relating to OECD forecasts for the United Kingdom and Sweden and Turner et al. (2018) for evidence relating to OECD forecasts more generally). ${ }^{3}$ This bias and skew makes it more difficult to assess and convey uncertainty surrounding GDP growth forecasts.

4. Previous OECD work has proposed a method to address these issues by constructing fan charts that are parameterised based on the historical forecasting track record, but distinguish between a "safe" regime and a "downturn-risk" regime (Turner et al., 2018). To identify the downturn-risk regime, the predicted probability of a future downturn from probit models are used. When there is a significant downturn probability, this probability is used to parameterise the downside skew in a fan chart based on the twopiece normal distribution. In the absence of a downturn risk, the fan chart uses a normal distribution based on root-mean square forecast error incurred over previous historical periods when there was little downturn risk.

5. The remainder of the paper is organised as follows. The next section describes the Bank of England and Riksbank approaches to parameterising fan charts. Section 3 describes a standard approach to estimating a probit model for predicting a future downturn, which is then applied to data for the United Kingdom and Sweden. Section 4 explains how the quarterly probit probabilities of a downturn are converted into a form that can be more easily related to annual forecast errors. Section 5 describes how the predicted downturn probabilities are used to parameterise fan charts around forecasts of GDP growth. In Section 6 the out-of-sample performance of this approach is evaluated by applying it to forecasts for the United Kingdom and Sweden made just prior to the GFC and by comparing it with the approach to parameterising fan charts used by the Bank of England and Riksbank. Finally, conclusions are drawn in Section 7.

\footnotetext{
${ }^{3}$ Forecast errors are sensitive to the vintage of outturn data they are judged against and while there is no obviously "correct" vintage to use, the use of the very latest vintage of outturns runs the risk of introducing "false errors" due to changes in the conceptual basis of GDP. Forecast errors for calendar year T are throughout this paper consistently evaluated relative to outturn in the May/June Economic Outlook published in year $(\mathrm{T}+1)$, which is consistent with previous OECD forecast evaluation exercises. The discussion below reports the results of some sensitivity testing to using later vintages of outturns to evaluate forecast errors.
} 


\section{Figure 1. OECD GDP growth forecast errors for the United Kingdom and Sweden}

Frequency distribution of pooled normalised errors for forecasts beyond the current year

(A) United Kingdom, Shapiro-Wilk test of normality $=5.12(<0.001 \%)$

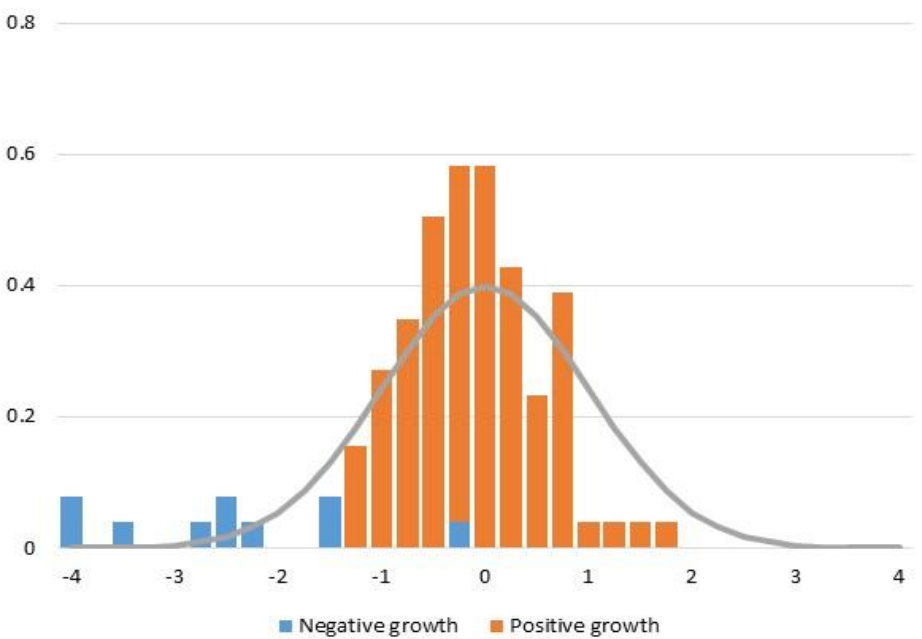

(B) Sweden, Shapiro-Wilk test of normality $=4.49(<0.001 \%)$

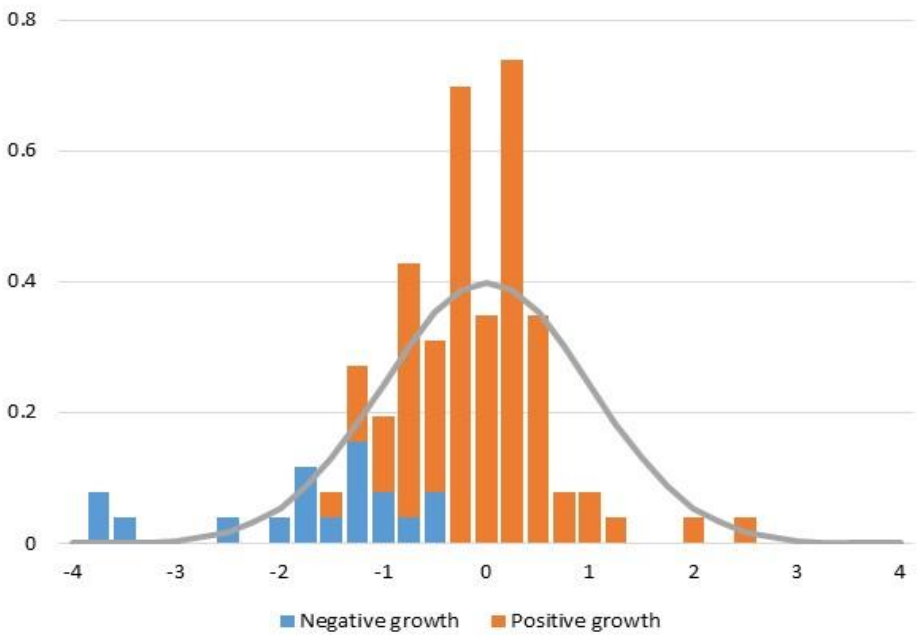

Note: These charts are designed to check whether OECD annual forecast errors of GDP growth for the United Kingdom and Sweden are normally distributed and unbiased at forecast horizons beyond the current year. The null hypothesis is that such forecast errors are normally distributed with zero mean, but with a country-specific variance that depends on the forecast horizon. Forecast errors are therefore normalised on each country's RMSE at each forecast horizon, namely: forecasts published in Spring for the year-ahead (sample period 1982-2017); published in the Autumn for the year-ahead (1980-2017); and published in the Autumn for two-years-ahead (1989-2017). The resulting standardised forecast errors are then pooled for each country and represented by the bars of the histogram. The bell-shaped curve shows the hypothetical frequency distribution of a standard normal variable, to which the histograms should converge under the null hypothesis. Bars or (segments of bars) coloured blue correspond to forecast errors during years in which there was an outturn of negative GDP growth. Shapiro-Wilk test statistics for normality, shown next to each chart (with the p-value for not rejecting the null of normality in brackets), confirm the visual impression of the charts, namely that the null hypothesis is overwhelmingly rejected at conventional levels of significance. 


\section{The Bank of England and Riksbank approaches to parameterising fan charts}

6. The Bank of England and Riksbank were the first to use fan charts in macroeconomic forecasting, although their use has since spread among many central banks as well as other major national and international institutions (see World Bank (2016) for a recent survey).

7. The term "fan chart" was coined by the Bank of England, which has been using such charts since 1997 in its Inflation Report to describe the uncertainty around its forecast of inflation and GDP growth. For the Bank of England, the width of the fan chart is initially based on the dispersion of outturns around previous forecasts, but this is then modified by the Monetary Policy Committee based on their judgement as to whether uncertainty looking forward is likely to be greater or less than that past experience, and whether risks are skewed to the up- or down-side (Britton et al., 1997; Bank of England, 2005).

8. The Riksbank has also published a Monetary Policy Report containing its inflation forecast with uncertainty bands around the forecast since 1997 . When the fan charts were first introduced, the underlying distribution was informed by model simulations of shocks that were judged likely to influence the forecast (Blix and Sellin, 1998). However, since 2007, Riksbank fan charts are based on historical errors, with fan chart bands calculated using the historical RMSE and assuming that errors are normally distributed, so implying symmetric fan charts (Sveriges Riksbank, 2007).

\section{A probit approach to quantifying downturn risks}

9. To identify downturn risks the approach here follows a well-developed literature in using probit models to assess the probability of a future downturn. ${ }^{4}$ Similar probit models to the ones estimated here for the United Kingdom and Sweden are estimated for the major seven OECD economies in Turner et al. (2018).

10. A severe downturn episode is here defined as a series of quarters in which: (i) GDP per capita falls in both the initial and final quarter of the episode; and (ii) the cumulative fall in GDP per capita is at least 2 percentage points over the entire episode. The dependent variable in the probit regression is then defined such that if that quarter is part of a severe downturn episode it takes the value unity and otherwise zero.

11. Separate probit models are estimated to assess the risk of a future downturn at horizons of 2, 4, 6 and 8 quarters ahead. Broadly speaking, two types of variables are tested for significance in the probit models, namely macro variables related to the business cycle and variables capturing developments in financial markets. The business cycle variables included are the slope of the yield curve and the unemployment gap. ${ }^{5}$ The financial market

\footnotetext{
4. See for example: Estrella and Mishkin (1997); Estrella (2007); Estrella et al. (2003); Dovern and Zieglar (2008); and Fornani and Lenke (2010).

${ }^{5}$ The derivation of the unemployment gap variable is described in detail in Rusticelli et al. (2015). Its use is more problematic than other explanatory variables, both because it is not official data and because it is subject to revision. Sensitivity analysis has found alternative measures of labour market slack (including a measure of the unemployment rate relative to a long moving average) to be often statistically significant, but inferior to the unemployment gap measure. For this reason, and because the process of generating the unemployment gap is closely related to the OECD Forecast Round procedures, the paper persists with the use of the unemployment gap. It should also be noted that
} 
variables included are those which previous OECD work (Hermansen and Röhn, 2017) has found to be most reliable in predicting future severe downturns at horizons of up to eight quarters across OECD countries, including credit growth, house prices and equity prices as well as international developments in financial markets, including measures of growth in OECD-wide credit and OECD-wide real house prices.

12. The sample estimation period is constrained by data availability, which for some important series are not available before 1970. Given these constraints, the approach followed here has been to have as long a sample estimation period as possible, particularly in order to maximise the number of downturn episodes that are covered. On the other hand, it might be argued that all advanced economies have undergone substantial structural change over this period, particularly in regard to financial market developments and hence the impact of financial variables on the macro-economy. However, sensitivity testing, not reported in detail here, suggests that the specifications used here are reasonably robust to a shorter estimation period. ${ }^{6}$

\subsection{Probit models for the United Kingdom}

13. In the case of the United Kingdom, four severe downturn episodes are identified since 1970, namely: 1973Q3-76Q2, 1979Q3-81Q1, 1990Q3-92Q2 and 2008Q2-09Q3. Five different explanatory variables are used across the four probit models (Table 1):

- A positive unemployment gap, implying a tight or over-heating labour market, signals an increased downturn risk at all (2, 4, 6 and 8 quarter) horizons. ${ }^{7}$

- A falling credit-to-GDP ratio increases downturn risk at horizons of 2 and 4 quarters.

- On the other hand, rapid sustained growth in the OECD-wide credit-to-GDP ratio over the previous three-year period increases the risk of a downturn at all horizons.

- The house-price-to-rent ratio also explains increased downturn risk, although the sign and functional form it takes vary with the horizon. At shorter horizons of 2 and 4 quarters it is recent short-term (one-year) falls in house prices which signal an increased downturn risk, whereas at longer (6 and 8 quarter) horizons it is sustained strong positive growth (over the previous five years) that signal increased downturn risk.

- Sustained rapid growth in real share prices (over the previous three-year period) also increase downturn risks at an horizon of 8 quarters.

recent revisions to the methodology underlying the derivation of the unemployment gap are likely to reduce the extent of real-time revisions (Rusticelli et al., 2015)

6. Keeping the same specification, but shortening the sample period to begin in 1980, gives a similar or improved goodness of fit (as measured either by the Mcfadden Rsqd or the \% of correct predictions), with virtually all coefficients remaining statistically significant (the only exceptions being the unemployment gap at 4 and 6 quarter horizons in the probit models for Sweden and the private credit variables at 2 and 4 quarter horizons in the probit models for the United Kingdom).

7. The unemployment gap is computed as the OECD's measure of equilibrium unemployment described in Rusticelli et al. (2016) less the actual unemployment rate. 
14. For the longer horizons, especially at 8 quarters, the fit of the model is improved by excluding the 1979/81 downturn. The reason for this is, as previously argued in Turner (2017), that the nature of the downturn in the early 1980s was very different, being driven by policy decisions to target the money supply in order to reduce inflation, which led to high interest rates and a marked appreciation of sterling (Buiter and Miller, 1981). In contrast, all other severe downturns in the United Kingdom were preceded by a sustained build-up in real house prices and rapid OECD-wide credit growth (Figure 2). ${ }^{8}$ The exclusion of the early-1980s downturn serves to underline a broader point, namely that although the model can predict most (here three out of four) downturns it will not predict atypical downturns. For example, in the current conjuncture, the models would be unlikely to predict a downturn that stemmed from a 'no-deal Brexit', because there is no experience of such an episode in the sample estimation period.

Figure 2. Characteristics of typical UK downturns
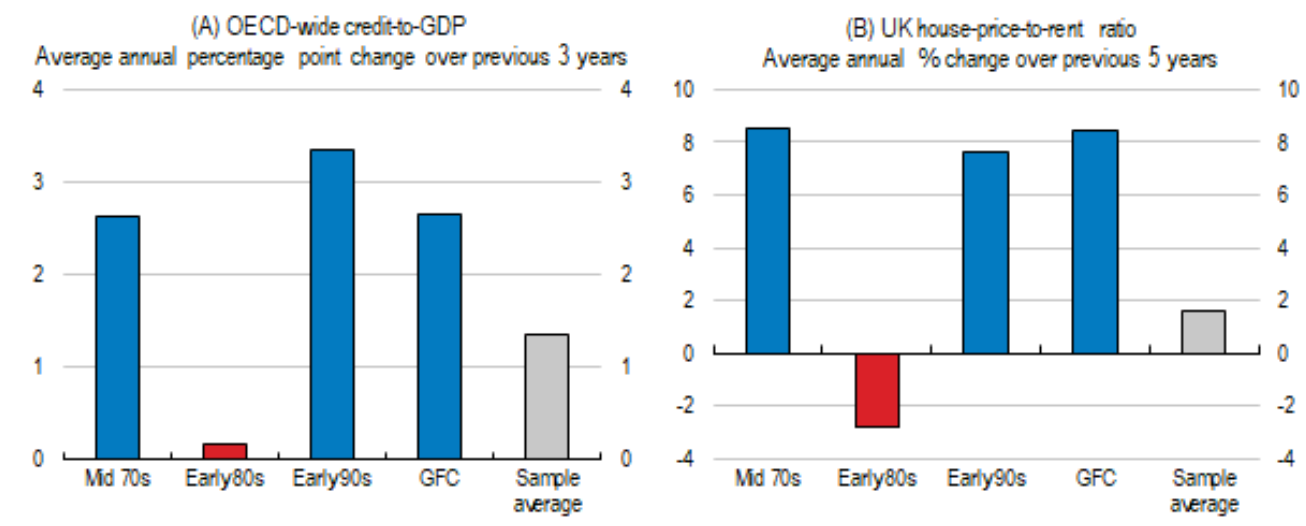

Note: Explanatory variables are shown in the form used in the 8-quarter UK probit model, 8 quarters ahead of each downturn, where 'Sample average' denotes the average over the full sample estimation period.

15. The overall goodness-of-fit and predictive power of the probit models remain quite high over all horizons, correctly predicting around $90 \%$ of future downturn and nondownturn episodes (Table 1 and Figure 3). False alarms (predicted downturns that did not materialise), particularly at longer (6-8 quarter) horizons, are most apparent in the four to five years preceding the GFC (Figure 3), but while these represent a statistical "failure" it is arguable that they might have represented a useful policy signal. On the other hand, the models perform poorly, especially at longer horizons, in predicting the downturn of the early 1980s (although as previously explained, this downturn is excluded from the estimation and from Figure 3).

8. Including the early 1980 s downturn, reduces the predictive fit of the probit model at an 8 -quarter horizon from $91 \%$ to $84 \%$, with the coefficients on some explanatory variables becoming insignificant, but there is less effect at shorter horizons. 
Figure 3. Downturn predictions of the probit models for the United Kingdom
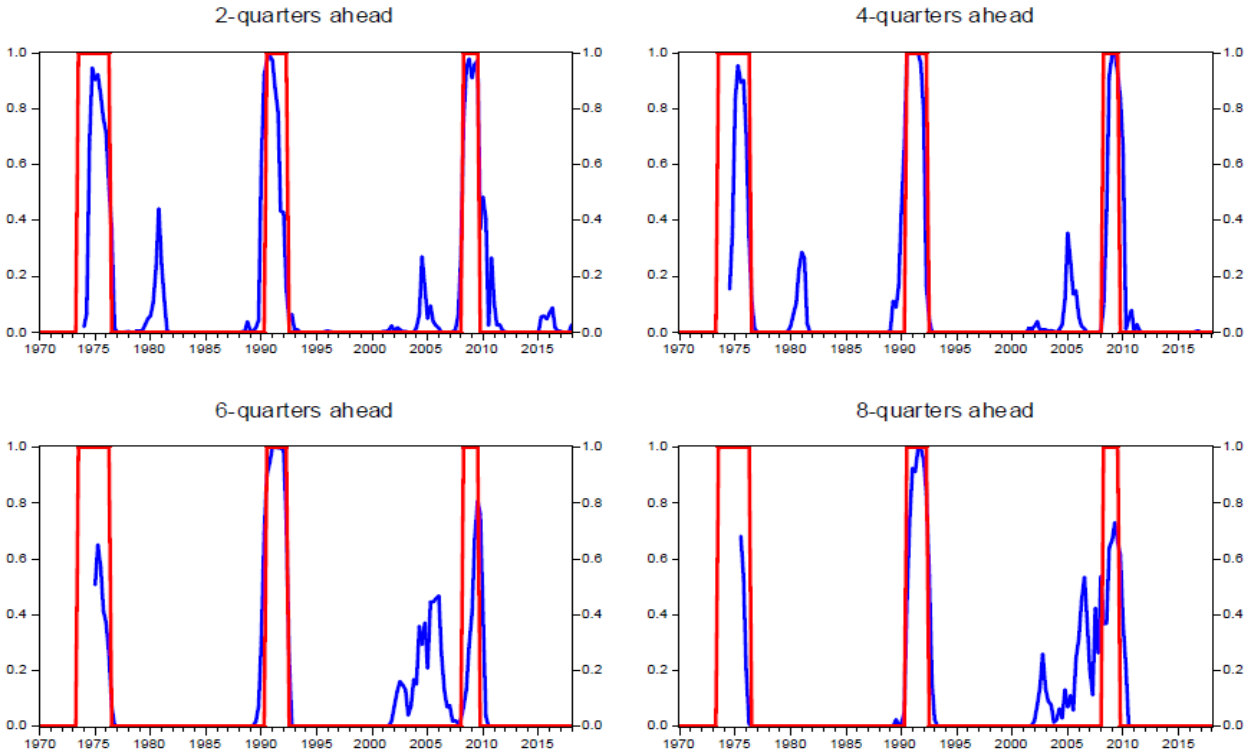

$$
\text { -Forecast - Actual }
$$

Note: The blue line shows the predicted probability of a severe downturn from the probit models. The red line takes a value of one or zero according to whether there is a downturn or not. 
Table 1. Probit regressions explaining downturns in the United Kingdom

\begin{tabular}{|c|c|c|c|c|c|}
\hline \multirow{3}{*}{$\begin{array}{l}\text { Binary dependent variable }{ }^{1} \text { : } \\
1=\text { severe downturn, } 0=\text { otherwise }\end{array}$} & \multirow[b]{3}{*}{$\begin{array}{l}\text { Standard } \\
\text { deviation }^{2}\end{array}$} & \multicolumn{4}{|c|}{ Probit regression at horizon of $Q$ quarters } \\
\hline & & $Q=2$ & $Q=4$ & $Q=6$ & $Q=8$ \\
\hline & & $\begin{array}{l}\text { 1974Q1- } \\
2018 Q 3\end{array}$ & $\begin{array}{l}\text { 1974Q3- } \\
\text { 2018Q3 }\end{array}$ & $\begin{array}{l}\text { 1975Q1- } \\
2018 Q 3\end{array}$ & $\begin{array}{l}\text { 1975Q3- } \\
2018 Q 3\end{array}$ \\
\hline Constant & & $-3.49^{* * *}$ & $-5.32^{\star * \star}$ & $-7.81^{* * *}$ & $-8.81^{* * *}$ \\
\hline Unemployment gap ${ }^{3}$ & 1.01 & $1.31^{* * *}$ & $2.39^{* * *}$ & $1.88^{* * *}$ & $1.28^{* *}$ \\
\hline \multicolumn{6}{|l|}{ Private credit-to-GDP ratio } \\
\hline 1-year annual change & 4.98 & $-0.23^{* * *}$ & $-0.19^{* *}$ & & \\
\hline \multicolumn{6}{|l|}{ Real share prices } \\
\hline 3-year annual average growth & 10.24 & & & & $0.10^{* * *}$ \\
\hline \multicolumn{6}{|l|}{ Price-to-rent ratio } \\
\hline 1-year annual growth & 9.31 & $-0.10^{* * *}$ & $-0.06^{* *}$ & & \\
\hline 5-year annual average growth & 5.09 & & & $0.29^{*}$ & $0.59^{* * *}$ \\
\hline \multicolumn{6}{|l|}{ OECD credit-to-GDP } \\
\hline 3-year annual average change & 1.59 & $1.14^{\star * *}$ & $1.47^{* * *}$ & $1.30^{* * *}$ & $0.95^{\star *}$ \\
\hline McFadden R-sqd & & 0.67 & 0.72 & 0.64 & 0.63 \\
\hline$\%$ of correct predictions ${ }^{4}$ & & $91 \%$ & $94 \%$ & $89 \%$ & $91 \%$ \\
\hline Downturns & & $92 \%$ & $95 \%$ & $90 \%$ & $94 \%$ \\
\hline Non-downturns & & $91 \%$ & $94 \%$ & $89 \%$ & $90 \%$ \\
\hline
\end{tabular}

Note:

1) The dependent variable is a binary variable taking the value of 1 in a severe downturn, defined as being during a run of quarters when real GDP per capita falls cumulatively by at least $2 \%$ points, and zero otherwise.

2) Standard deviation of the explanatory variable over the full sample.

3) The unemployment gap is the OECD measure of the NAIRU less the unemployment rate, so that a positive value indicates that the labour market is over-heating.

4) Predictions categorised according to a $15 \%$ probability threshold, where $15 \%$ is roughly the share of all quarters during which a large sample of OECD countries experience a downturn.

For the probit regression at a horizon of $\mathrm{Q}$ quarters $(\mathrm{Q}=2,4,6$ or 8$)$ all explanatory variables enter the equations lagged by $Q$ quarters except house price variables which are lagged an extra quarter and credit variables which are lagged two quarters (reflecting the timeliness in data availability). Statistical significance of coefficients at the $1 \%, 5 \%$ and $10 \%$ levels are denoted by '***', '**' and '*”, respectively.

Source: OECD Analytical Database and Bank for International Settlements. 


\subsection{Probit models for Sweden}

16. In the case of Sweden, four severe downturn episodes are identified since 1970: 1976Q2-78Q1, 1990Q2-93Q4, 2008Q1-09Q3 and 2011Q4-13Q2. The four probit equations use different combinations of seven explanatory variables (Table 2):

- At horizons of 2, 4 and 6 quarters a negatively slope yield curve is a predictor of a future downturn, with a stronger marginal effect at shorter horizons.

- At horizons of 4 and 6 quarters, a positive unemployment gap, implying a tight or over-heating labour market, signals a future downturn.

- House prices have an important influence, although the sign and functional form varies with the horizon: short-term (one-year) falls in real house prices signal an increased risk at a 2 quarter horizon; a sustained (three-year) increase in real house prices increases risk at 2 and 4 quarter horizons; and at longer horizons the ratio of house-prices-to personal-disposable-income signals increased downturn risk.

- Rapid growth in bank-credit-to-GDP ratio increases risk at an 8-quarter horizon.

- OECD-wide variables are included at all horizons: at shorter horizons, one-year falls in real house prices signal an increased downturn risk; whereas at longer horizons sustained rapid growth in the credit-to-GDP ratio signals a downturn.

17. The overall goodness-of-fit and predictive power of the probit models remain quite high over all horizons, correctly predicting around $80-90 \%$ of future downturn and nondownturn episodes (Table 2). This good fit is confirmed by the fitted values that predict quite closely the four major downturns episodes, with the possible exception of the 8-quarter model that fails to differentiate the GFC and the euro-debt crisis (Figure 4). The apparent false alarms in the early 1980's (and to a lesser extent in the early 2000's) are partly explained by the fact that these correspond to periods of weakness in GDP, although this weakness was not sufficient to cross the threshold defining a severe downturn. ${ }^{9}$

9. For example, GDP per capita growth in Sweden averaged only $1 / 2$ percentage point at annualised rate between the final quarter of 1980 and the first quarter of 1983 (compared to an average of nearly $2 \%$ pa over the 1970s), although this weakness does not qualify as a severe downturn. 
Figure 4. Downturn predictions of the probit models for Sweden
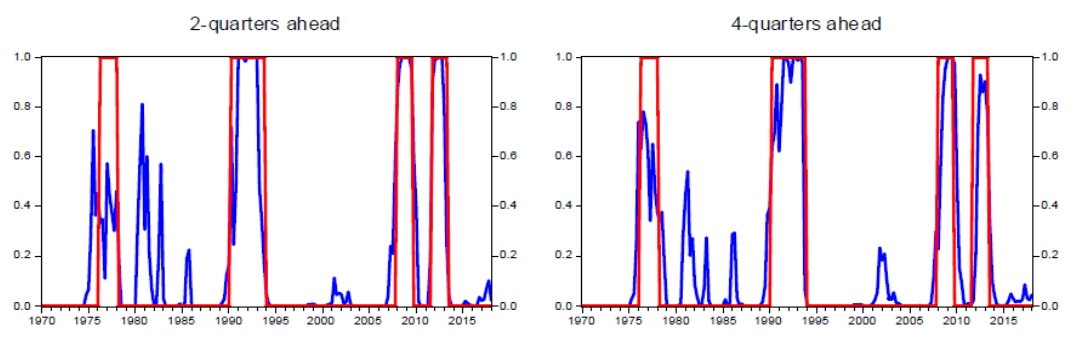

6-quarters ahead

8-quarters ahead
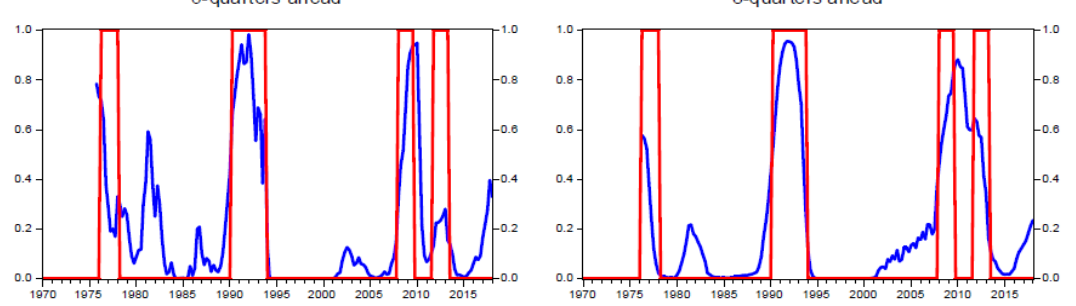

- Forecast _-Actual

Note: The blue line shows the predicted probability of a severe downturn from the probit models. The red line takes a value of one or zero according to whether there is a downturn or not. 
Table 2. Probit regressions explaining downturns in Sweden

\begin{tabular}{|c|c|c|c|c|c|}
\hline \multirow{3}{*}{$\begin{array}{l}\text { Binary dependent variable }{ }^{1} \text { : } \\
\begin{array}{l}1=\text { sev ere dow nturn, } \\
0=\text { otherwise }\end{array}\end{array}$} & \multicolumn{5}{|c|}{ Probit regression at horizon of $Q$ quarters } \\
\hline & \multirow[b]{2}{*}{$\begin{array}{c}\text { Standard } \\
\text { deviation }{ }^{2}\end{array}$} & \multirow{2}{*}{$\frac{Q=2}{1973 Q 4-2018 Q 3}$} & \multirow{2}{*}{$\frac{Q=4}{1974 Q 2-2018 Q 3}$} & \multirow{2}{*}{$\frac{Q=6}{1975 Q 4-2018 Q 3}$} & \multirow{2}{*}{$\frac{Q=8}{1976 Q 2-2018 Q 3}$} \\
\hline & & & & & \\
\hline Constant & & $-1.16^{* * *}$ & $-1.07^{\star \star *}$ & $-4.58^{\star \star \star}$ & $-3.32^{* \star *}$ \\
\hline Yield curve & 1.25 & $-1.55^{\star \star *}$ & $-0.98^{* \star *}$ & $-0.44^{* \star *}$ & \\
\hline Unemploy ment gap $^{3}$ & 1.53 & & $0.48^{* *}$ & $0.43^{* * *}$ & \\
\hline \multicolumn{6}{|l|}{ Priv ate credit-to-GDP ratio } \\
\hline 3-y ear annual avg change & 3.51 & & & & $0.18^{* * *}$ \\
\hline \multicolumn{6}{|l|}{ Real house prices } \\
\hline 1-y ear annual growth & 6.86 & $-0.16^{* \star *}$ & & & \\
\hline 3-y ear annual avg growth & 5.67 & $0.47^{* * *}$ & $0.21^{* * *}$ & & \\
\hline House-price-to-income ratio & 14.99 & & & $0.04^{* * *}$ & $0.02^{*}$ \\
\hline \multicolumn{6}{|l|}{ OECD credit-to-GDP } \\
\hline 3-y ear annual avg change & 1.02 & & & $0.57^{* * *}$ & $0.56^{\star * *}$ \\
\hline \multicolumn{6}{|l|}{ OECD real house prices } \\
\hline 1-y ear annual growth & 3.19 & $-0.60^{* * *}$ & $-0.43^{\star \star \star}$ & & \\
\hline 3-y ear annual avg growth & 2.56 & & & & \\
\hline McFadden R-sqd & & 0.69 & 0.65 & 0.43 & 0.41 \\
\hline$\%$ of correct predictions ${ }^{4}$ & & 88 & 86 & 81 & 89 \\
\hline Dow nturns & & 97 & 95 & 95 & 92 \\
\hline Non-dow nturns & & 86 & 84 & 78 & 89 \\
\hline
\end{tabular}

Note:

1) The dependent variable is a binary variable taking the value of 1 in a severe downturn, defined as being during a run of quarters when GDP per capita falls cumulatively by at least $2 \%$ points, and zero otherwise.

2) Standard deviation of the explanatory variable over the full sample.

3) The unemployment gap is the OECD measure of the NAIRU less the unemployment rate, so that a positive value indicates that the labour market is over-heating.

4) Predictions categorised according to a $15 \%$ probability threshold.

For the probit regression at a horizon of $\mathrm{Q}$ quarters $(\mathrm{Q}=2,4,6$ or 8$)$ all explanatory variables enter the equations lagged by $\mathrm{Q}$ quarters except house price variables which are lagged an extra quarter and credit variables which are lagged two quarters (reflecting the timeliness in data availability). Statistical significance of coefficients at the $1 \%, 5 \%$ and $10 \%$ levels are denoted by '***', '**' and '*”, respectively.

Source: OECD Analytical Database and Bank for International Settlements.

\section{Linking quarterly probit probabilities to annual downturn risks}

18. While OECD forecasts published in the OECD Economic Outlook do have a quarterly profile, the forecasts themselves are more commonly discussed in annual form, 
partly reflecting the large number of countries that the forecasts cover. In order to represent the risk around the annual GDP growth forecasts, it is first necessary to convert the quarterly probit probabilities of a downturn risk into the corresponding risk for an annual forecast. In computing the annualised downturn risk, the predictions from the probit models covering only a subset of quarters $(2,4,6$ and 8 quarters) are used for reasons of tractability, particularly given the goal of applying a similar approach across a number of OECD countries.

19. The calculation of an annual risk measure, and in particular how it is related to the quarterly probit probabilities, depends on the forecast horizon (Figure 5). For example, consider a Spring forecast that is published towards the end of the second quarter in year $\mathrm{T}$, where it can be assumed that data are available for the first quarter of year $\mathrm{T}$ at the time of publication (Figure 5, panel B). The risk of a downturn is then calculated as a weighted average of the probit probabilities of a future downturn two, four and six quarters in advance. From the perspective of the first quarter of year $\mathrm{T}$ (for which the most recent data will be available), this corresponds to a weighted average of a downturn in the third quarter of year $\mathrm{T}$ and the first and third quarters of year $(\mathrm{T}+1)$. The probabilities are given weights reflecting the importance of the quarterly growth rates in the calculation of annual growth of year $(\mathrm{T}+1)$ relative to year $\mathrm{T}$ (Cross and Wyman, 2011). Thus, in this case of the Spring year-ahead forecast, the probability of a downturn in the first quarter of year $(\mathrm{T}+1)$ is given double the weight of the probabilities of a downturn in the third quarter of years $\mathrm{T}$ and $(\mathrm{T}+1)$. Annual probabilities can be calculated for the Spring current-year, Autumn oneyear-ahead and Autumn two-year-ahead forecasts in a similar fashion.

\section{Designing fan charts to reflect downturn risks}

20. The approach to parameterising a fan chart advocated here is based on past forecast errors, but with the risk of a future severe downturn derived from the quarterly probit models also reflected in the dispersion of the fan chart as follows: ${ }^{10}$

- If the risk of a future downturn is very low, so that the annual probability of a downturn is below a threshold value (here arbitrarily taken to be 5\%), it is assumed that possible outcomes are normally distributed around the published forecast, which is assumed to be the modal outcome. Given the symmetry of the normal distribution, the modal outcome is also the mean outcome. The dispersion of possible outcomes is based on the historical RMSE of forecast errors during periods in which the probit probability was below the threshold value, which will typically be smaller than the RMSE over the entire forecast track record.

- If the risk of a downturn according to the probit model is significant (above the threshold value), then possible outcomes are assumed to be skewed to the downside, with the extent of the skew related to the size of the downturn risk. In this case, forecast errors are assumed to follow a two-piece normal distribution, which is parameterised by using the historical relationship between downturn probabilities and past forecast errors, as described below.

${ }^{10}$ An alternative approach to characterising forecast uncertainty would be to consider a bimodal distribution in which growth outcomes are characterised by two normal distributions depending on the risk of recession [see for example, Hamilton (2016)]. 


\section{Figure 5. Relating quarterly probit probabilities to annual probabilities}

(A) Autumn year-ahead forecast

Probability of a downturn, $\mathrm{P}^{\mathrm{A}, \mathrm{T}+1}=(2 / 3)^{*} \mathrm{p}_{2}+(1 / 3)^{*} \mathrm{p}_{4}$

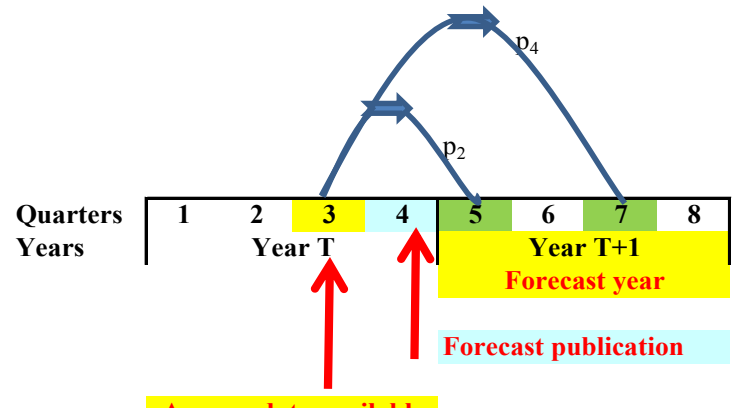

Assume data available

(B) Spring year-ahead forecast:

Probability of a downturn, $\mathrm{P}^{\mathrm{S}, \mathrm{T}+1}=0.25 * \mathrm{p}_{2}+0.5 * \mathrm{p}_{4}+0.25 * \mathrm{p}_{6}$

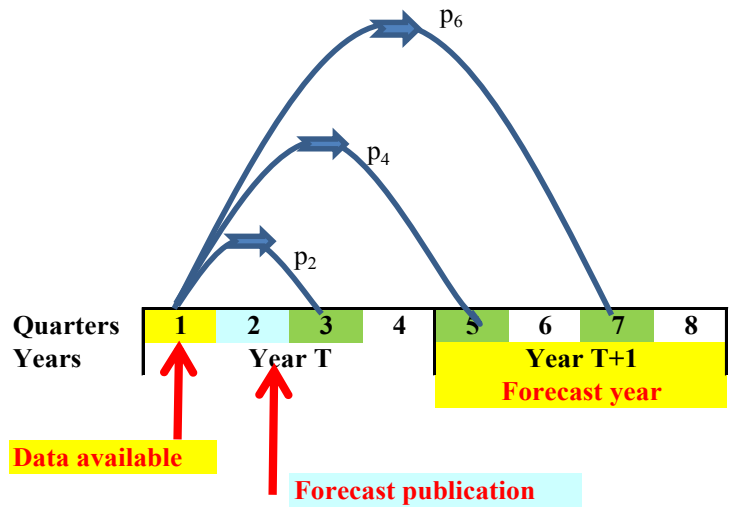

(C) Autumn two-year-ahead forecast:

Probability of a downturn, $\mathrm{P}^{\mathrm{A}, \mathrm{T}+2}=0.25 * \mathrm{p}_{4}+0.5 * \mathrm{p}_{6}+0.25 * \mathrm{p}_{8}$

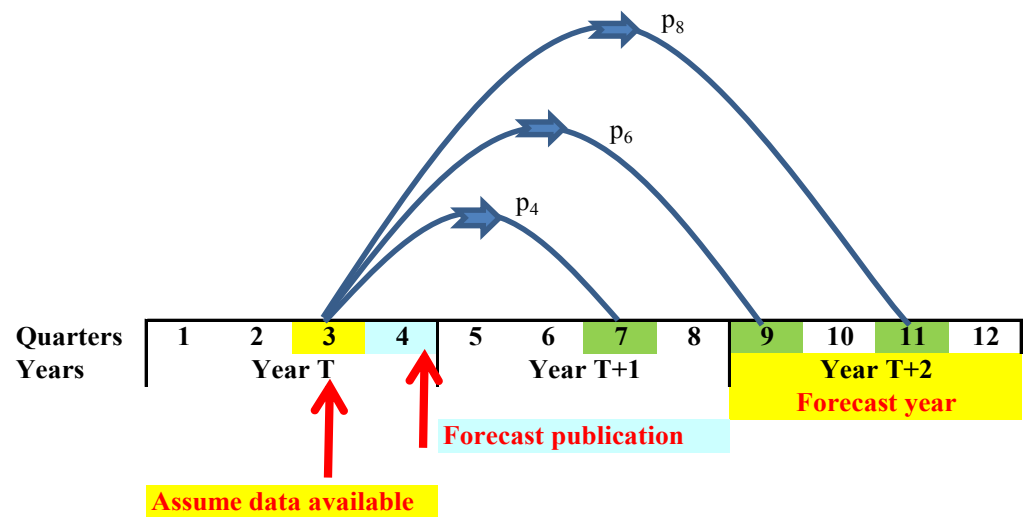

Note: The chart summarises how quarterly probit probabilities, $\mathrm{p}_{\mathrm{n}}$, of a future downturn at an horizon of $\mathrm{n}$ quarters $(n=2,4,6$, or 8$)$ are converted to an annual probability of a future downturn, $\mathrm{P}^{\mathrm{s}}$, $\mathrm{T}+\mathrm{i}$, where $\mathrm{s}$ represents whether the forecast is published in the Spring $(\mathrm{s}=\mathrm{S})$ or Autumn $(\mathrm{s}=\mathrm{A})$ of year $\mathrm{T}$ and the forecast is for year $(\mathrm{T}+\mathrm{i})$, where the forecast horizon is $\mathrm{i}=1$ or 2 years. A Spring (Autumn) forecast is published towards the end of the second (fourth) quarter, so that most data for the quarterly probit model will be available up to the first (third) quarter. 
21. The current paper follows the Bank of England in using the two-piece normal distribution to model the distribution of risks when they are skewed, although the approach to parameterising it differs; here the degree of uncertainty (the overall spread of the fan chart) is based on past forecast errors, but the skew (reflecting whether risks are tilted to the down-side) is derived from the probability of a future downturn derived from the estimated probit models.

22. The two-piece normal distribution can be summarised in terms of three parameters -- the mode $(\mu)$ and two standard deviations $\left(\sigma_{1}\right.$ and $\left.\sigma_{2}\right)$-- and is formed by taking two halves of normal distributions with parameters $\left(\mu, \sigma_{1}\right)$ and $\left(\mu, \sigma_{2}\right)$, and scaling them so that the probability density functions have a common value at the mode.. With $\sigma_{1}$ $>\sigma_{2}$ the distribution will have negative skewness, and the relationship between the mean outcome $\left(\mu^{*}\right)$ and mode is given by (see John, 1982):

$\mu-\mu^{*}=\mathrm{k}\left(\sigma_{1}-\sigma_{2}\right)$, where $\mathrm{k}=(2 / \pi)^{1 / 2}$.

23. To estimate the three parameters of the two-piece normal distribution for the downturn-risk regime, the following assumptions are made:

- The published forecast is the modal outcome, $\mu$.

- The smaller standard deviation, $\sigma_{2}$, of the upper half of the distribution can be approximated by the RMSE of forecast errors in periods when there is deemed to be little risk of a downturn (i.e. when the probit probability of a downturn is less than $5 \%$ ). The reasoning is that if the outcome exceeds the published forecast so that there is no severe downturn, then there is little reason to expect the forecast error to be exceptional and hence it can be evaluated by the past forecast performance during safe periods.

- The larger standard deviation, $\sigma_{1}$, of the lower half of the distribution is computed by first quantifying the historical relationship between the mean forecast error and the probit probability of a downturn. Any observed non-trivial probability of a downturn can be converted into a predicted mean forecast error, which then, given the assumptions for $\mu$ and $\sigma_{2}$ above, can be used to determine $\sigma_{1}$ using equation (1).

24. The relationship between the mean forecast error and the probit probability of a downturn is estimated from a regression of historical annual forecast errors, $\epsilon_{t}^{s, t+i}$ distinguishing whether the associated forecasts were published in the Spring $(\mathrm{s}=\mathrm{S})$ or Autumn ( $s=A$ ) of year $t$ and for which year $(t+i)$ the forecasts were made (where $i=0,1$ or 2 ). Thus, separate regressions of the form of equation (2) are run for each of: the Spring current year forecast errors $\left(\epsilon_{t}^{S, t}\right)$; the Spring year-ahead forecast errors $\left(\epsilon_{t}^{S, t+1}\right)$; the Autumn year-ahead forecast errors; $\left(\epsilon_{t}^{A, t+1}\right)$; and the Autumn two-year-ahead forecast error $\left(\epsilon_{t}^{A, t+2}\right)$. Thus, regressions take the following form:

$\epsilon_{t}^{s, t+i}=\beta_{0}+\beta_{1} P_{t}^{s, t+i}$,

where $P_{t}^{s, t+i}$ is the corresponding annualised probability of a downturn derived from the quarterly probit model probabilities. In all cases, care is taken to ensure that data used to 
assess the future downturn probability would have been available at the time the forecast was published. ${ }^{11}$

\section{Parameterising fan charts for the United Kingdom and Sweden}

25. The approach described in the previous section is applied to the United Kingdom and Sweden; forecast errors are regressed on the corresponding risks of a downturn in the period being forecast, with separate regressions distinguishing when the forecast was made (Spring or Autumn) and the forecast horizon (current year, year-ahead or two-years-ahead) (Tables 3 and 4). The main results are as follows:

- The estimated coefficients $\left(\beta_{1}\right)$ on the downturn probability is strongly statistically significant, large and negative for both Spring and Autumn forecasts and for all horizons beyond the current year, implying that increased risk of a downturn is strongly associated with forecast over-predictions. Thus, for example, a $50 \%$ probability of a downturn is associated with over-predictions of between $13 / 4$ and 2 percentage points for the United Kingdom and between 1 and 1 1 $\frac{2}{2}$ percentage points for Sweden, depending on the forecast horizon.

- The intercept term $\left(\beta_{0}\right)$ is relatively small and mostly statistically insignificant, suggesting that when the probability of a future downturn is negligible then forecasts are unbiased.

- An exception to these results is the Spring current-year forecast, where the $\beta_{1}$ coefficient is much smaller and less statistically significant than the corresponding coefficients estimated at longer horizons. This is consistent with the finding that current-year forecasts appear unbiased with errors that are normally distributed (Turner et al., 2018). This finding is perhaps not entirely surprising, given that by the time of the Spring forecast publication (at the end of May or in early June), growth outturns for the first quarter will be known and hard monthly indicators will provide guidance on the second quarter outcome and these two quarters represent a substantial weight in the annual growth outcome for the current year.

- Sensitivity testing has been carried out to check whether these results are sensitive to which vintage of outturn data forecast errors are calculated against. The variation appears only modest, for example: the $\beta_{1}$ parameter in the UK regression for two-yearahead forecast errors changes from -3.7 to $-3.7,-3.9$ and -4.0 as forecast errors for year $\mathrm{T}$ are computed on outturns from years $(\mathrm{T}+1),(\mathrm{T}+2),(\mathrm{T}+3)$ and $(\mathrm{T}+4)$ errors; similarly for Sweden, the variation in the same coefficient is $-4.8,-5.3,-5.2$ and -5.2 .

\footnotetext{
${ }^{11}$ Two further details of how the fan charts are constructed here are discussed in Annex B of Turner et al (2018), namely: the use of highest density intervals rather than central prediction intervals; and the number of prediction intervals that are distinguished. Both are important in determining the appearance of the fan chart, but neither is central to the main argument about the importance of distinguishing downturn risks.
} 
Table 3. Regressions of forecast errors for the United Kingdom on downturn probabilities

\begin{tabular}{|c|c|c|c|c|}
\hline \multirow[b]{2}{*}{ Forecast published in } & \multicolumn{4}{|c|}{ Dependent variable: forecast error, $\epsilon_{t}(\mathrm{~s}, \mathrm{t}+\mathrm{i})$} \\
\hline & Spring & Autumn & Spring & Autumn \\
\hline Forecast horizon & curent-y ear & year-ahead & year-ahead & 2-y ears-ahead \\
\hline Sample period & $1981-2017$ & $1980-2017$ & $1982-2017$ & 1989-2017 \\
\hline Intercept term, $\left(\beta_{0}\right)$ & 0.07 & $0.27^{*}$ & 0.17 & -0.18 \\
\hline Downturn probability $P_{t}^{(s, t+i)},\left(\beta_{1}\right)$ & $-0.93^{* *}$ & $-3.54^{* * *}$ & $-4.25^{\star \star *}$ & $-3.72^{* * *}$ \\
\hline R-sqd adjusted & 0.12 & 0.53 & 0.47 & 0.28 \\
\hline
\end{tabular}

Note: Statistical significance of coefficients at the $1 \%, 5 \%$ and $10 \%$ levels are denoted by ' $* * *$ ’, ‘**' and '*”, respectively.

Table 4. Regressions of forecast errors for Sweden on downturn probabilities

\begin{tabular}{lcccc}
\hline & \multicolumn{4}{c}{ Dependent variable: forecast error, $\epsilon_{\mathrm{t}}{ }^{(\mathrm{s}, \mathrm{t+i})}$} \\
\cline { 2 - 5 } Forecast published in & Spring & Autumn & Spring & Autumn \\
Forecast horizon & curent-year & year-ahead & year-ahead & 2-years-ahead \\
Sample period & $1981-2017$ & $1980-2017$ & $1982-2017$ & $1989-2017$ \\
\hline Intercept term, $\left(\beta_{0}\right)$ & -0.07 & 0.07 & 0.11 & 0.32 \\
Downturn probability $\mathrm{P}_{\mathrm{t}}^{(\mathrm{s}, \mathrm{t+i})},\left(\beta_{1}\right)$ & -0.48 & $-2.13^{* * *}$ & $-4.24^{* * *}$ & $-4.83^{* * *}$ \\
R-sqd adjusted & 0.40 & 0.38 & 0.62 & 0.54 \\
\hline
\end{tabular}

Note: Statistical significance of coefficients at the $1 \%, 5 \%$ and $10 \%$ levels are denoted by '***', ‘**' and '*”, respectively.

\section{Fan charts prior to the Global Financial Crisis}

26. As a means of comparing the different approaches to constructing fan charts, their performance is compared when applied to forecasts made just prior to the financial crisis, published around mid-2008. Given that the Bank of England approach is mostly based on the judgement of the Monetary Policy Committee (MPC), the only way to evaluate the approach is to examine how the MPC exercised that judgment in relation to Bank of England forecasts for the United Kingdom published at the time. On the other hand, the Riksbank method is more mechanical and so can easily be applied to other forecasts. Thus, as well as considering the Riksbank fan charts published around their own forecasts for Sweden, the Riksbank methodology is also applied to OECD forecasts of both the United Kingdom and Sweden.

27. For comparative purposes, the fan charts parameterised on the basis of probit models are run strictly as out-of-sample exercises, so that no data beyond 2008Q1 are used, directly or indirectly, to compute the fan charts. This requires that all the quarterly probit regressions of downturn risk as well as the regression of forecast errors on annualised risks are rerun on the reduced sample. As the unemployment gap is computed with trend components, which are subject to historical revisions, the re-estimated equations use those series published at the time of the June 2008 Economic Outlook. Reducing the sample period has little effect on the goodness-of-fit of the probit regressions and the majority of explanatory variables remain statistically significant and correctly signed. Similarly, the 
slope coefficients $\left(\beta_{1}\right.$ 's) remain large and statistically significant in the regressions linking forecast errors and annualised downturn probabilities (see Annex A for details).

\subsection{Forecasts for the United Kingdom}

\subsubsection{OECD June 2008 forecast}

28. The June 2008 Economic Outlook forecast for the United Kingdom implied a slowdown in GDP growth from about 3\% per annum in 2006-7 to 13/4 per cent in 2008 and $1 \frac{1}{2}$ per cent in 2009 . While these forecasts did not include any explicit quantitative assessment of risk, the commentary on individual country forecasts did provide a descriptive assessment. In the case of the United Kingdom this commentary appears quite prescient: "There are downside risks to growth... For example, GDP growth could slow more markedly if financial sector health continues to deteriorate or if the housing market falls into a more significant slump".

29. A fan chart is first computed using the Riksbank method based on OECD historical forecast errors (for the United Kingdom), assuming they are normally distributed and unbiased. The outturn for GDP growth in 2009 of $-5 \%$ is well below the $90 \%$ prediction interval of the resulting fan chart (Figure 6, Panel A).

30. A second fan chart is then computed using the probit methodology described above, but using the regressions based on pre-crisis data to parameterise the skew in the fan chart. At the time of the publication of the June 2008 forecast, using data that was available in the first quarter, the annualised risk of a downturn in 2009 is computed as $75 \%$, which implies a skew (the difference between the mean and mode) of 3.2 percentage points. There are a combination of factors underlying this high downturn probability at the beginning of 2008: the large sustained increases in the house-price-to-rent ratio and the growth rate of real share prices over the preceding several years; the more recent fall in real house prices over the preceding year; a positive unemployment gap (indicating labour market overheating); and all against a background of sustained strong growth in OECD-wide credit. This degree of skew implies risks to the 2009 GDP forecast are strongly tilted to the downside with the outturn for GDP growth being within the $70-90 \%$ prediction interval (Figure 6, Panel B). 
Figure 6. Fan charts for the June 2008 Economic Outlook UK GDP growth forecast

(A) Symmetric fan chart based on the Riksbank method

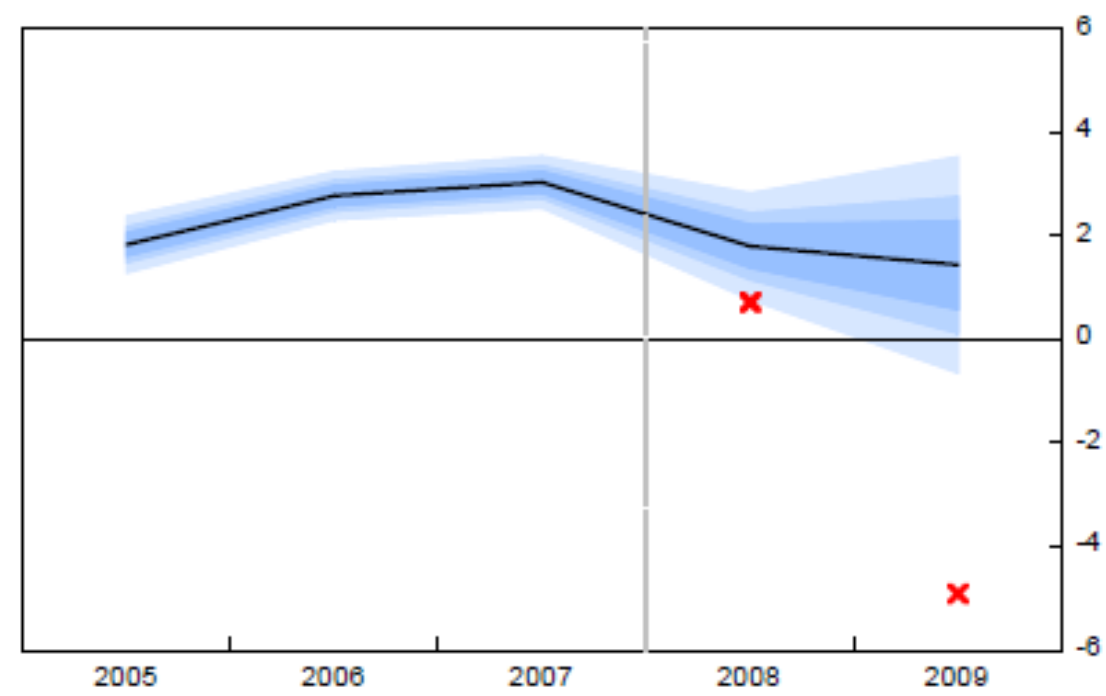

(B) Asymmetric fan chart based on the probit models

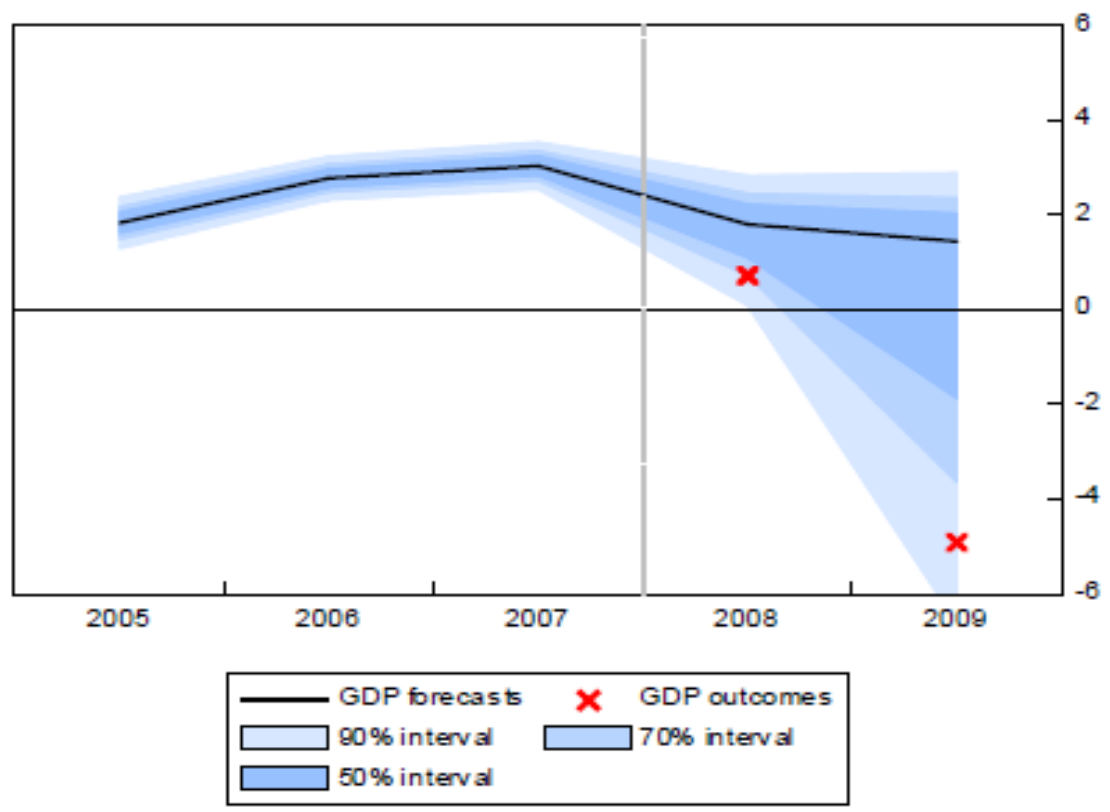

Note: Shaded blue areas show successively the $50 \%, 70 \%$ and $90 \%$ prediction intervals. The solid black line is the outturn up to 2007 and the projection for 2008 and 2009, as reported in the June 2008 Economic Outlook. The red crosses show the outturn according to the Economic Outlook published in the year following the first outturn data. The prediction intervals around the historical growth path reflect the extent to which historical estimates of GDP growth are subsequently revised. 


\subsubsection{Bank of England May 2008 forecast}

31. The Bank of England's May 2008 Inflation Report forecast of GDP implies an annual growth rate for calendar year 2009 that is very similar to that projected by the OECD in the June 2008 OECD Economic Outlook. The Inflation Report commented on the "intensification of stresses in global financial and credit markets" and that "risks around demand are judged to be balanced in the near term, but lie to the downside in the medium term". However, the quantification of the negative skew in the fan chart for GDP growth was negligible and barely discernible in the fan chart published alongside the forecast. ${ }^{12}$ The lower bound of the $90 \%$ confidence interval of the fan chart for annualised GDP growth borders on the zero axis for every quarter in 2009 , implying a low probability that annual GDP growth would be negative for calendar year 2009 (Figure 7).

Figure 7. The Bank of England's May 2008 Inflation Report fan chart

GDP growth (quarter on same quarter of previous year, \% per annum)

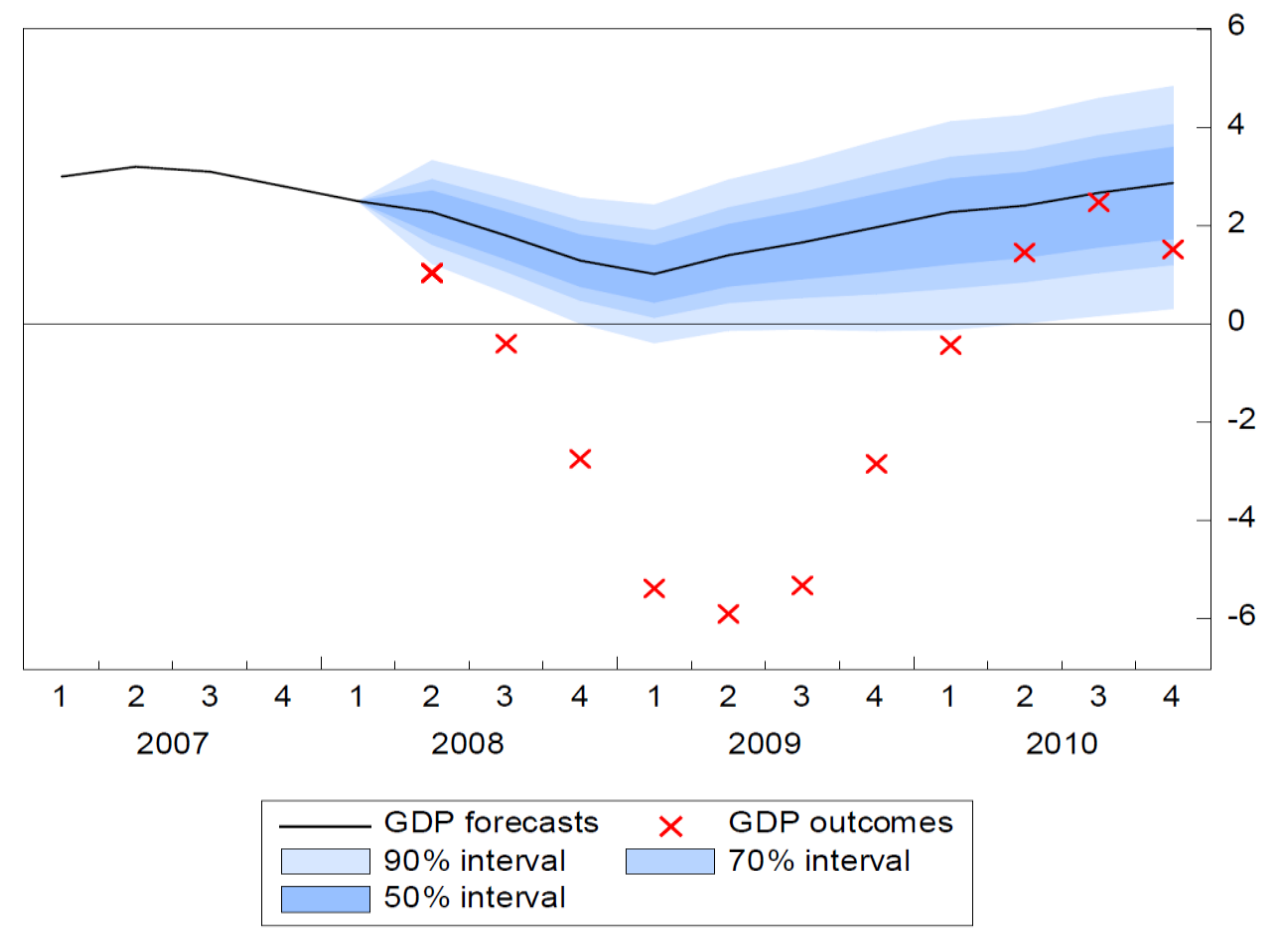

Note: Authors' representation of the fan chart published in the Bank of England's May 2008 Inflation Report, based on parameters underlying the fan chart distribution published by the Bank. There are cosmetic differences compared to the version appearing in the Inflation Report; in particular, the Bank's version distinguished prediction intervals at every $10 \%$ and intervals around historical data also represent the possibility that such data is subsequently revised. The red crosses show the outturn according to the Economic Outlook published in the year following the first outturn data.

Source: Authors' calculations based on parameters published with the Inflation Report, May 2008.

12. The extent of negative skew in the fan chart underlying the Bank of England's GDP growth projection only increased from -0.06 in 2009 Q3 to a maximum of -0.2 in 2010 . More surprisingly, the degree of negative skew in the Bank of England's GDP fan chart remained trivial in the November 2009 Inflation Report, even after the bankruptcy of Lehman Brothers. 
32. The GDP growth outturns for 2008 and 2009 were well outside the $90 \%$ prediction intervals of the Bank of England's fan chart. ${ }^{13}$ In order to convey the extent of these 'misses', the probability of the outturns can be compared with the probability of being struck down by lightning within the course of a year, which is estimated by Calman and Royston (1997) to be 1 in 10 million. On this basis, the outturns in 2009Q1 and 2009Q3 were, on the basis of the published parameters underlying the Bank of England's fan charts, much less likely to have occurred than being struck down by lightning, and the outturn for 2009Q2 was less likely than being struck down twice in one year.

\subsubsection{Bank of England November 2007 forecast}

33. The Bank of England's forecast published in November 2007 Inflation Report, bear many similarities with the forecast published in May 2008 discussed above, in particular the outturns for 2009 and 2010 were well outside the outer bounds of the fan chart (Figure 8). However, the earlier forecast is worth highlighting here, because on the one hand the description of risks seems particularly prophetic, as evidenced by the following excerpts from the Inflation Report:

"The balance of risks around this central case is on the downside. First, the global financial system remains vulnerable to further shocks. Second, even without further shocks, the price and availability of credit may tighten by more than assumed in the central projection, as current uncertainties about the valuation and location of lenders' exposures are resolved. And, third, any significant decline in asset prices could materially weaken household and corporate balance sheets, and the associated collateral provided to lenders.

.... The balance of risks to world growth is on the downside. The slowdown in the US housing market may start to bear more heavily on other parts of the US economy, or spread elsewhere .... Renewed financial market turbulence could lead to a further tightening in credit conditions, a decline in global equity and other asset prices.."

34. On the other hand, the degree of skew in the accompanying fan chart is trivial, never exceeding 0.15 percentage points (for annualised growth) for any quarter over the forecast horizon, so that it is barely discernible in the fan chart.

13. Outturns are here judged according to the data published in the Spring 2011 OECD Economic Outlook. 
Figure 8. The Bank of England's November 2007 Inflation Report fan chart

GDP growth, \% change on a year earlier

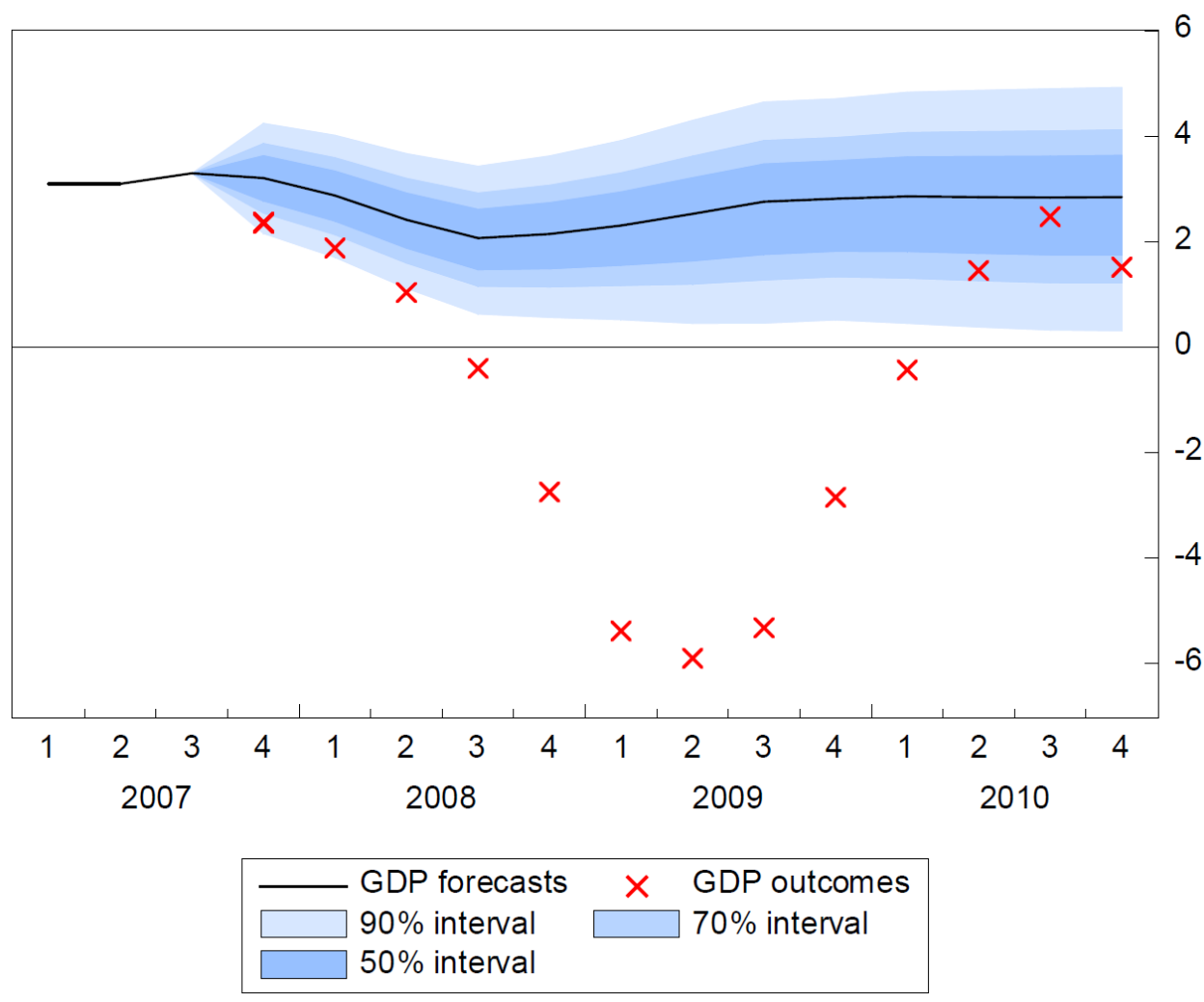

Note: This figure represents the authors' representation of the Bank of England's fan chart published in the Bank's November 2007 Inflation Report, based on the parameters underlying the fan chart distribution published by the Bank. There are cosmetic differences compared to the version appearing in the Inflation Report; in particular, the Bank's version distinguished prediction intervals at every $10 \%$ and intervals around historical data also represent the possibility that such data is subsequently revised. The solid black line is the outturn up to 2007 Q3 and the projection thereafter. Red crosses show the outturn according to the Economic Outlook published in the year following the first outturn data.

Source: Authors calculations based on fan chart parameters published with the Bank of England's Inflation Report, November 2007. 


\subsection{Forecasts for Sweden}

\subsubsection{OECD June 2008 forecast}

35. The OECD forecast published in the June 2008 Economic Outlook was for a slowdown in growth for the Swedish economy, but to rates of about $2 \%$ per annum in 2008 and 2009. Again, although there was no formal quantification of risks, the commentary accompanying the June 2008 Economic Outlook forecasts for Sweden appears quite prescient: "Downside risks to the Swedish economy arise from the direct and indirect effects of international economic developments. Export markets might slow more than expected, directly reducing GDP growth. In addition, if international financial market stress were to spill over more seriously to the Swedish financial sector, borrowing costs would rise and confidence would deteriorate further, compounding the slowdown in domestic demand. Of particular concern is the high exposure of Swedish banks to the Baltic States."

36. A fan chart is first computed using the Riksbank method based on (OECD) historical forecast errors, assuming they are normally distributed and unbiased. The outturn for GDP growth in both 2008 and, especially, 2009 is well below the $90 \%$ prediction interval of the resulting fan chart (Figure 9, Panel A).

37. A second fan chart is then computed using the probit methodology, but using the regressions based on pre-crisis data to parameterise the skew in the fan chart. At the time of the publication of the June 2008 forecast, the latest data for the explanatory variables entering the probit models imply a high degree of negative skew, particularly: the large sustained increases in real house prices and the high level of the house-price-to-income ratio; a positive unemployment gap (indicating labour market overheating); a flat yield curve; and all against a background of sustained strong growth in OECD-wide real house prices and bank credit. This degree of skew implies risks to the 2009 GDP forecast are strongly tilted to the downside with the outturn for GDP growth being (just) within the 7090\% prediction interval (Figure 9, Panel B). 
Figure 9. Fan charts for the June 2008 Economic Outlook GDP growth forecast of Sweden

(A) Symmetric fan chart based on the Riksbank method

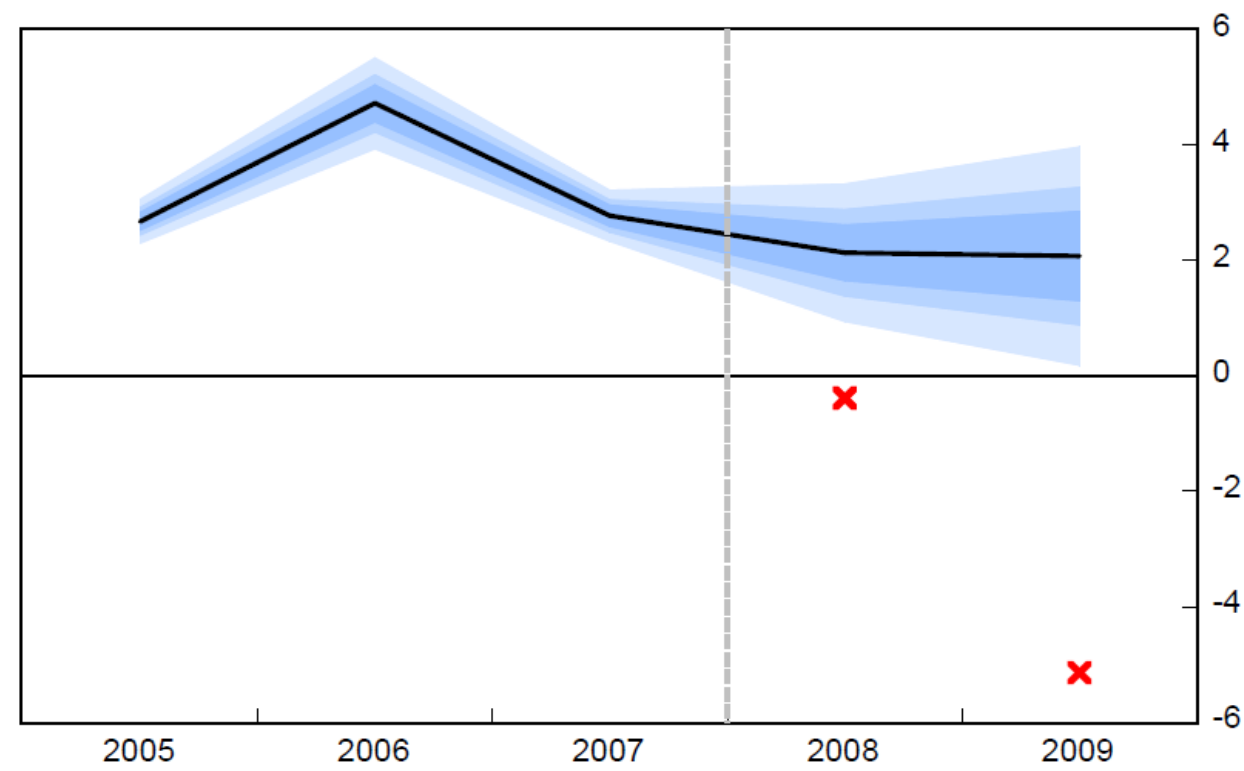

(B) Asymmetric fan chart based on the probit models

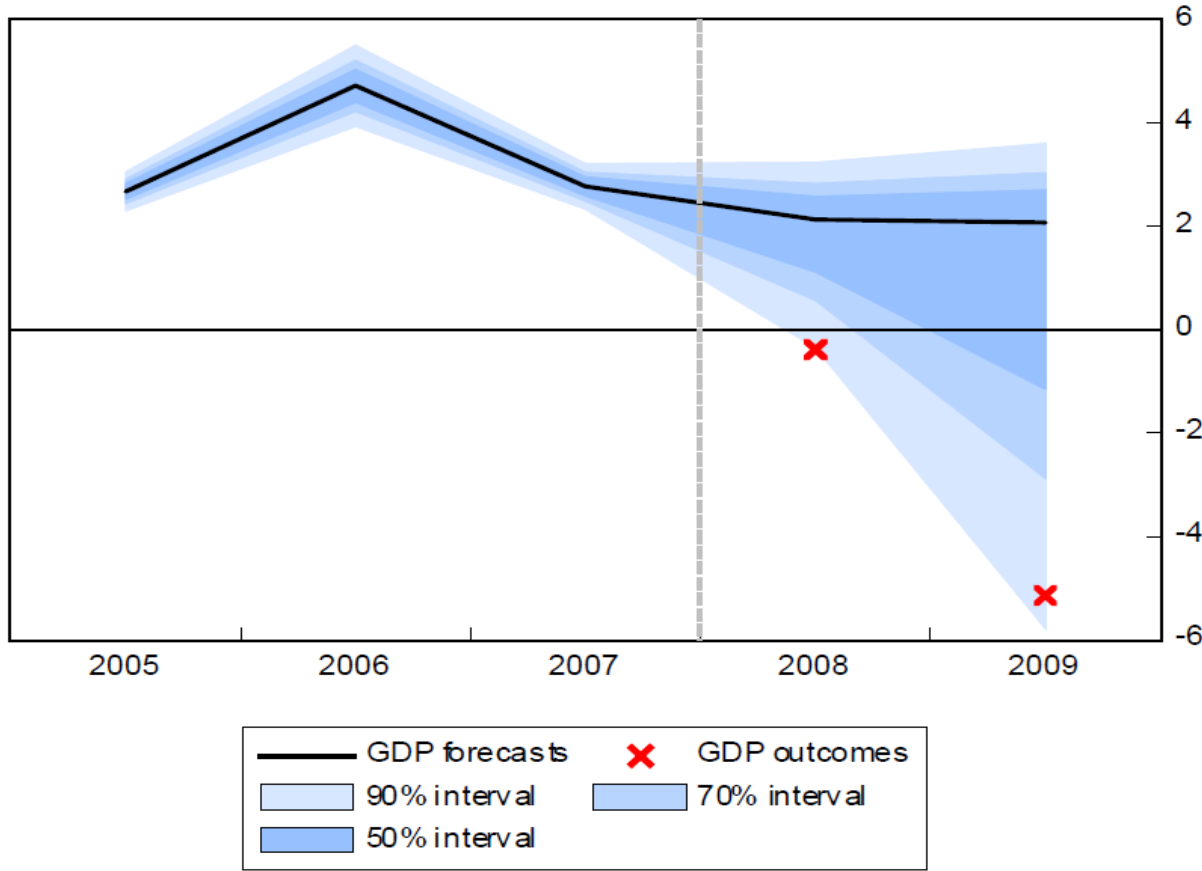

Note: Shaded blue areas show successively the $50 \%, 70 \%$ and $90 \%$ prediction intervals. The solid black line is the outturn up to 2007 and the projection for 2008 and 2009, as reported in the June 2008 Economic Outlook. The red crosses show the outturn according to the Economic Outlook published in the year following the first outturn data. The prediction intervals around the historical growth path reflect the extent to which historical estimates of GDP growth are subsequently revised. 


\subsubsection{Riksbank July 2008 forecast}

38. The central forecast published by the Riksbank in their July 2008 Monetary Policy Report was for GDP growth to weaken, but remain positive in 2008 and 2009. The commentary in the Monetary Policy Report emphasised downside risks to the forecast, although with a focus on a possible shock emanating from the Baltic States: "The uncertainty in the financial markets will probably persist and this means that there is considerable vulnerability to shocks. For instance, events in the Baltic countries could provide a shock. ... This would reinforce the turmoil in the financial markets and lead to a further increase in the banks' financing costs. Ultimately, this would lead to higher interest rates for Swedish households and companies."

39. Unfortunately, given the mechanical method underlying the construction of the Riksbank fan charts, these downside risks are not reflected in the skew of the fan chart that was published alongside the forecast, which remained symmetrical around the central forecast (Figure 10). The GDP growth outturns for 2008 and 2009 were consequently well outside the $90 \%$ prediction intervals of the Riksbank's fan chart. ${ }^{14}$ In order to convey the extent of these 'misses', the probability of the outturns can again be compared to the probability of being struck down by lightning within the course of a year. On this basis, the outturns from 2008Q4 to 2009Q3 were all much less likely to have occurred than being struck down by lightning.

14. The 'bounce back' from the downturn in 2010 is also well above the upper boundary of the fan chart in Figure 10. This might prompt the more general question as to whether there is ever a need to build in upward skew to the fan chart, particularly in the recovery phase following a downturn. However, the distribution of OECD forecast errors for Sweden and the United Kingdom suggests that extreme under-predictions are rare (see Figure 1), a result which is borne out for other major OECD countries (Turner et al, 2018), although this may partly be because the latter results relate to annual growth forecasts rather than the quarterly profile used in the Riksbank's fan charts. 
Figure 10. The Riksbank's July 2008 Monetary Policy Report fan chart

GDP growth, \% change on a year earlier

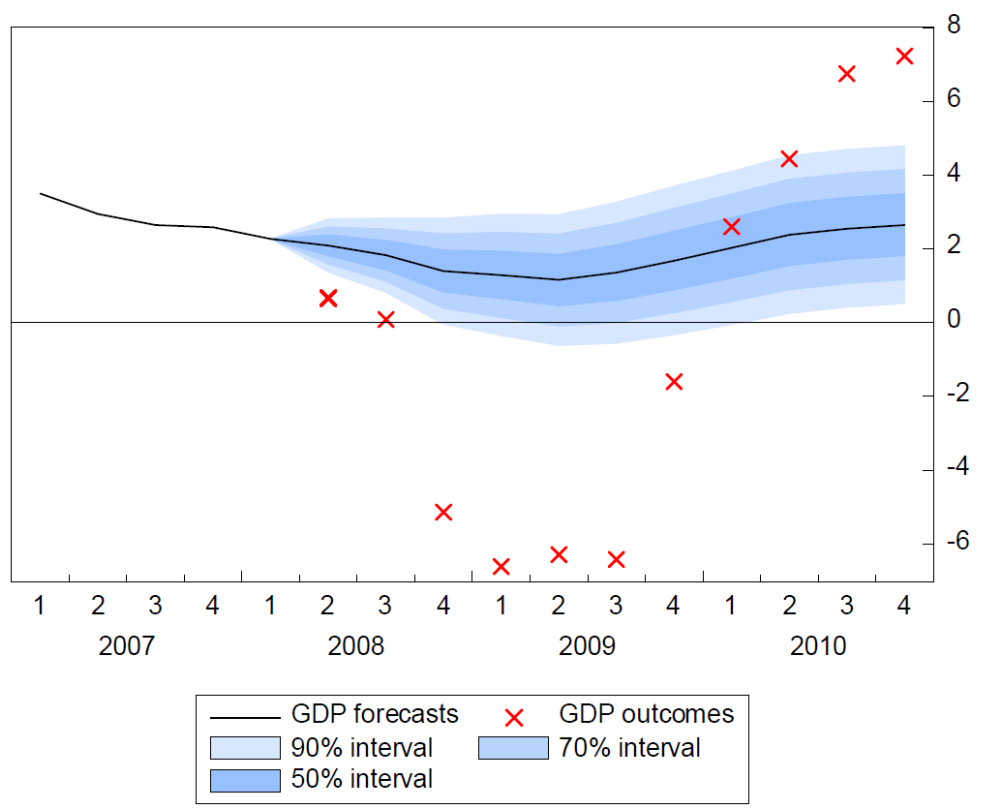

Note: This figure represents the authors' representation of the Riksbank's fan chart published in their July 2008 Monetary Policy Report, based on parameters inferred from the fan chart prediction intervals published by the Riksbank. The solid black line is the outturn up to 2008 Q1 and the projection thereafter. The prediction intervals are calibrated based on past forecast errors assuming they are normally distributed and hence symmetrically distributed, see Sveriges Riksbank (2007) for details. The red crosses show the outturn according to the Economic Outlook published in the year following the first outturn data.

Source: Sveriges Riksbank July 2008 Monetary Policy Report.

\section{Summary and conclusions}

40. This paper has described a method for designing fan charts for GDP growth forecasts based on historical forecast errors that recognises that forecasters have a poor track record in predicting future downturns. The proposed methodology uses the probabilities from probit models at different forecast horizons to quantify the risk of a future downturn. The relationship between these probabilities and past forecast errors is then used to parameterise the downwards skew in a fan chart.

41. For both Sweden and the United Kingdom, the explanatory variables which help to predict downturns at longer horizons (up to 8 quarters) include sustained rapid growth in house prices and credit, at both the national and OECD-wide level and (for the United Kingdom) rapid sustained growth in real equity prices. Tight labour markets can contribute to downturn risk at all horizons. At shorter horizons (2-4 quarters) recent sharp falls in house prices or credit presage a downturn, implying that there may be a point of inflexion in these variables ahead of a typical downturn. For Sweden, a negatively sloped yield curve is also a risk factor for a future downturn, especially at shorter horizons. Similar combinations of variables are found to explain downturn risks in other OECD economies (Turner et al., 2018). 
42. The probit-based method is illustrated for the United Kingdom and Sweden, and compared with the current approaches of the Bank of England and Riksbank, the two institutions that pioneered the use of fan charts, by applying them to forecasts made immediately prior to the GFC. On the basis of this specific episode, the probit-based fan charts clearly out-perform the Bank of England and Riksbank approaches. The fan charts generated from the Riksbank and Bank of England approaches imply that the occurrence of the GFC was very much less likely than the probability of being struck down by lightning, whereas the GFC lies well within conventional prediction intervals of fan charts calibrated on probit model predictions, even when such predictions are made on an out-ofsample basis.

43. These fan chart examples also serve to highlight more fundamental weaknesses with the Bank of England and Riksbank approaches.

- The Riksbank approach of parameterising fan charts under the implicit assumption that forecast errors are normally distributed can clearly be contradicted by the risk commentary accompanying the forecasts that will inevitably sometimes imply that risks are not balanced. Moreover, the assumption that forecast errors have a normal distribution is almost certainly at odds with the historical track record. Under these circumstances it is difficult to understand what purpose the fan chart serves because it is neither an accurate representation of past forecast errors nor is it a reflection of the risk assessment underlying the baseline forecast.

- The Bank of England approach to fan chart parameterisation relies heavily on the judgment of experts (in their case the members of the Monetary Policy Committee) to assess risks. As illustrated in excerpts quoted in this paper, forecasters' ability to qualitatively recognise risks is not infallible. But even when they do correctly foresee the nature of future risks -- as for example appears to be the case for the Bank of England's November 2007 Inflation Report forecast -- the quantitative translation of these risks into the fan chart skew has been far too timid.

44. Perhaps one reason explaining this timidity is that, on average, the magnitude of historical forecast errors is typically quite large at horizons beyond the current year, implying that if these are the basis for parameterising the fan chart, then the prediction intervals will already be quite wide. Hence further exaggerating this spread by adding skew might suggest that practically any outcome is possible and so may appear unpalatable, or even embarrassing. The approach advocated in this paper partially addresses this issue because it distinguishes forecast errors during periods when there is a risk of a downturn from years when there is no such risk. The RMSE of the latter is typically much smaller (by up to one-half ${ }^{15}$ ) than the RMSE over the full sample, and this is what is used both as the basis of the fan chart when there is no downturn risk and for the upper part of the prediction intervals (representing the possibility of under-prediction) when there is a downturn risk. Importantly in this context, this tends to compress the width of the fan chart before applying any degree of downward skew associated with downturn risk. This in turn might mean that forecasters are less reluctant (or embarrassed) to apply downward skew to the fan chart. In addition, acknowledging the large forecast errors that are typically made during historical downturn episodes and using them to calibrate downward skew clearly supports a more bold approach when there is a risk of a downturn.

15. See Table 4 of Turner et al. (2018). 
45. More mechanical statistical approaches to calibrating fan charts, such as that adopted by the Riksbank, do have the merit of avoiding 'false alarms' which may be wrongly signalled based on inadequate economic modelling or faulty judgment regarding future risks. On the other hand, most of the downturn false alarms issued from the probit models considered here, either correspond to: periods of weak growth, but which didn't qualify as a downturn (for example Sweden in the early 1980s); or might nevertheless have been helpful from a policy perspective in giving advance warning of tensions that led to a future severe downturn (for example, the premature 6 and 8 quarter risks which were signalled for both Sweden and the United Kingdom in the years ahead of the GFC).

46. The more judgemental approaches to calibrating fan charts, such as that adopted by the Bank of England, do have the merit of being better able to better accommodate a wide range of risks. Conversely, a weakness of the probit model-based approach is that it will not predict atypical downturns, such as the UK downturn associated with the Thatcher government's experiment with monetarism in the early 1980s. In the context of the current macroeconomic conjuncture, this suggests it would be unlikely to predict a downturn associated with a no-deal-Brexit, or a global trade war. On the other hand, there is no downward skew reflecting these factors in any of the GDP growth fan charts published in the Bank of England's Inflation Reports during 2018, although this stands in contrast to adverse scenarios of a "disruptive" or "disorderly" Brexit detailed in a separate analysis published by the Bank recently (Bank of England, 2018).

47. The probit-based approach to calibrating fan charts described in this paper, does help to predict a clear majority of previous severe downturns as borne out by the current work, as well as similar work on other OECD countries (Turner at al., 2108), and so may be helpful in predicting downturns that follow the pattern of previous typical businessfinancial cycles. Moreover, a downturn triggered by atypical events may be more severe if more typical risk factors are also high. 


\section{References}

Abreu, I. (2011), "International Organisations' vs Private Analysts' Forecasts: An Evaluation", Banco de Portugal Working Papers, 20/2011, July.

Bank of England (2005), "Assessing the MPC's Fan Charts", Bank of England Quarterly Bulletin.

Bank of England (2007), Inflation Report, November.

Bank of England (2008), Inflation Report, May.

Bank of England (2018), EU Withdrawal Scenarios and Monetary and Financial Stability: A Response to the House of Commons Treasury Committee, November.

Blix, M. and P. Sellin (1998), "Uncertainty Bands for Inflation Forecasts", Sveriges Riksbank Working Paper Series, No. 65.

Boero, G., Smith, J., and Wallis, K. F. (2015), "The Measurement and Characteristics of Professional Forecasters' Uncertainty”, Journal of Applied Econometrics, vol. 30: 1029-1046. doi: 10.1002/jae.2400.

Britton, E., P. Fisher and J. Whitley (1997), "Asymmetry, Risks and a Probability Distribution of Inflation", Bank of England Quarterly Bulletin,

Buiter, W. and M. Miller (1981), "The Thatcher Experiment: The First Two Years", Brookings Papers on Economic Activity, Vol. 2.

Calman, K. and G. Royston G. (1997) "Risk language and dialects", British Medical Journal; 315:939-42.

Casella, G. and R. Berger (2002), Statistical inference, Second Edition, Duxbury Advanced Series.

Cross, P. and D. Wyman (2011), "The Relationship between Monthly, Quarterly and Annual Growth Rates", Canadian Economic Observer, June.

Dovern, J. and C. Zieglar (2008), "Predicting Growth Rates and Recession. Assessing US Leading Indicators under Real Time Conditions", Working Paper 1397, Kiel University.

Estrella, A. (2007), "Why does the Yield Curve Predict Output and Inflation?" Economic Journal, 115:722-44.

Estrella, A and F. S. Miskin (1997), "The Predictive Power of the Term Structure of Interest Rates in Europe and the United States: Implications for the European Central Bank", European Economic Review, 41:1375-1401.

Estrella, A., A. Rodrigues and S. Schich (2003), "How Stable is the Predictive Power of the Yield Curve? Evidence from Germany and the United States", Review of Economics and Statistics, 85:629-644.

Fildes, R. and Steckler, (2002), "The state of macroeconomic forecasting", Journal of Macroeconomics, 24(2), pp. 435-468. 
Romei, V. and K. Fray (2018), "IMF shows poor track record at forecasting recessions", Financial Times, April 9.

Fornari, F. and W. Lemke (2010), "Predicting Recession Probablities with Financial Variables over Multiple Horizons", ECB Working Paper Series, No. 1255, October.

Hamilton, J. (2016), "Macroeconomic Regimes and Regime Shifts", NBER Working Paper No. 21863, January.

Hermansen, M and O. Röhn (2017), "Economic resilience: The usefulness of early warning indicators in OECD countries", OECD Journal: Economic Studies, No. 1, Vol. 2016, Issue 1, pp. 9-35. OECD Publishing, Paris. DOI:

http://dx.doi.org/10.1787/eco_studies-2016-5jg2ppjrd6r3

John, S. (1982), "The three-parameter two-piece normal family of distributions and its fitting", Communications in Statistics - Theory and Methods, 11(8), pp. 879-885. DOI: http://dx.doi.org/10.1080/03610928208828279

Loungani, P. (2001), "How Accurate are Private Sector Forecasts? Cross-Country Evidence from Consensus Forecasts of Output Growth", International Journal of Forecasting, 17(3), pp. 410-432

OECD (1990), OECD Economic Outlook, No. 47, Vol. 1990/1, June, OECD Publishing, Paris. DOI: http://dx.doi.org/10.1787/eco_outlook-v1990-1-en

OECD (2008), OECD Economic Outlook, No. 83, Vol. 2008/1, June, OECD Publishing, Paris. DOI: http://dx.doi.org/10.1787/eco_outlook-v2008-1-en

Pain, N. and C. Lewis (2014), "Lessons Learned from OECD Forecasts During and after the Financial Crisis", OECD Journal: Economic Studies, No. 5, Vol. 2104, Issue, 1, pp. 9-39, OECD Publishing, Paris. DOI: http://dx.doi.org/10.1787/eco_studies2014-5jxrcm2glc7j

Rusticelli, E., D. Turner and M. Cavalleri (2015), "Incorporating Anchored Inflation Expectations in the Phillips Curve and in the Derivation of OECD Measures of Equilibrium Unemployment", OECD Economics Department Working Papers, No. 1231, OECD Publishing, Paris. DOI: http://dx.doi.org/10.1787/5js1gmq551wden

Sveriges Riksbank (2007), "Calculation Method for Uncertainty Bands", Monetary Policy Report, 2007:1

Sveriges Riksbank (2008), Monetary Policy Report, 2008:2.

Sveriges Riksbank (2007), Monetary Policy Update, December.

Stark, T. (2010), "Realistic Evaluation of Real-Time Forecasts in the Survey of Professional Forecasters", Research Rap Special Report, https://ideas.repec.org/a/fip/fedprr/y2010imayx1.html.

Tay, A. S., and K. F. Wallis (2000), "Density Forecasting: A Survey", Journal of Forecasting, 19, pp. 235-254.

Turner, D. (2017), "Designing Fan Charts for GDP Growth Forecasts to Better Reflect Downturn Risks, OECD Economics Working Papers, No. 1428, OECD Publishing, Paris. DOI: http://dx.doi.org/10.1787/e86flbfc-en 
Turner, D., T. Chalaux and H. Morgavi (2018), "Fan Charts around GDP Projections Based on Probit Models of Downturn Risk", OECD Economics Working Papers, No. 1521, OECD Publishing.

Wallis, K. F. (2014), "The Two-Piece Normal, Binomial, or Double Gaussian Distribution: Its Origin and Rediscoveries", Statistical Science, Vol. 29, No. 1, pp. 106-112, https://projecteuclid.org/euclid.ss/1399645739

Wallis, K. F. (2004), "An Assessment of Bank of England and National Institute Forecast Uncertainties", National Institute Economic Review, No. 189, July.

Wallis K F. (1999), "Asymmetric Density Forecasts of Inflation and the Bank of England's Fan Chart", National Institute Economic Review, January.

World Bank (2016), "Quantifying Uncertainties in Global Growth Forecasts", Special Focus 2 in Global Economic Prospects, June. 


\section{Annex A. Pre-GFC sample estimation results}

Table A1. Probit regressions explaining downturns in the UK at different horizons, over a full sample and pre-GFC sample

\begin{tabular}{|c|c|c|c|c|c|c|c|c|c|}
\hline \multirow{4}{*}{$\begin{array}{l}\text { Binary dependent variable }{ }^{1} \text { : } \\
1=\text { severe downturn, } 0=\text { otherwise }\end{array}$} & \multicolumn{9}{|c|}{ Probit regression at horizon of $Q$ quarters } \\
\hline & \multirow{3}{*}{$\begin{array}{c}\text { Standard } \\
\text { deviation }\end{array}$} & \multirow{3}{*}{$\begin{array}{c}Q=2 \\
1974 Q 1- \\
2018 Q 3\end{array}$} & \multirow{3}{*}{$\begin{array}{c}Q=2 \\
\text { 1974Q1- } \\
\text { 2008Q1 }\end{array}$} & \multirow{3}{*}{$\begin{array}{c}Q=4 \\
1974 Q 3- \\
2018 Q 3\end{array}$} & \multirow{3}{*}{$\begin{array}{c}Q=4 \\
1974 Q 3- \\
2008 Q 1\end{array}$} & \multirow{3}{*}{$\begin{array}{c}\mathrm{Q}=6 \\
1975 \mathrm{Q} 1- \\
2018 \mathrm{Q}\end{array}$} & \multirow{3}{*}{$\begin{array}{c}Q=6 \\
1975 \mathrm{Q} 1- \\
2008 \mathrm{Q} 1\end{array}$} & \multirow{3}{*}{$\begin{array}{c}Q=8 \\
1975 Q 3- \\
2018 Q 3\end{array}$} & \multirow{3}{*}{$\begin{array}{c}\mathrm{Q}=8 \\
1975 \mathrm{Q} 3 \\
2008 \mathrm{Q} 1 \\
\end{array}$} \\
\hline & & & & & & & & & \\
\hline & & & & & & & & & \\
\hline Constant & & $-3.49^{* \star *}$ & $-4.49^{\star \star \star}$ & $-5.32^{\star \star \star}$ & $-10.42^{\star *}$ & $-7.81^{\star * \star}$ & $-12.32^{\star \star *}$ & $-8.81^{* * *}$ & $-8.93^{\star \star \star}$ \\
\hline Unemployment gap ${ }^{3}$ & 1.01 & $1.31^{\star * *}$ & $0.86^{* * *}$ & $2.39^{* * \star}$ & $3.39^{*}$ & $1.88^{\star \star \star}$ & $6.20^{\star \star \star}$ & $1.28^{* \star}$ & $4.43^{* *}$ \\
\hline \multicolumn{10}{|l|}{ Private credit-to-GDP ratio } \\
\hline 1-year annual change & 4.98 & $-0.23^{* * *}$ & $-0.40^{\star \star *}$ & $-0.19^{* *}$ & $-0.60^{*}$ & & & & \\
\hline \multicolumn{10}{|l|}{ Real share prices } \\
\hline 3-year annual average growth & 10.24 & & & & & & & $0.10^{* \star *}$ & 0.06 \\
\hline \multicolumn{10}{|l|}{ Price-to-rent ratio } \\
\hline 1-year annual growth & 9.31 & $-0.10^{* * *}$ & $-0.08^{\star * *}$ & $-0.06^{* *}$ & $-0.11^{* *}$ & & & & \\
\hline 5-year annual average growth & 5.09 & & & & & $0.29^{*}$ & $0.58^{\star}$ & $0.59^{\star \star \star}$ & $0.66^{* *}$ \\
\hline \multicolumn{10}{|l|}{ OECD credit-to-GDP } \\
\hline 3-year annual average change & 1.59 & $1.14^{* * *}$ & $2.03^{* * *}$ & $1.47^{* * *}$ & $4.04^{* *}$ & $1.30^{* * *}$ & 0.57 & $0.95^{* *}$ & -0.39 \\
\hline McFadden R-sqd & & 0.67 & 0.69 & 0.72 & 0.83 & 0.64 & 0.84 & 0.63 & 0.77 \\
\hline$\%$ of correct predictions ${ }^{4}$ & & $91 \%$ & $92 \%$ & $94 \%$ & $95 \%$ & $89 \%$ & $99 \%$ & $91 \%$ & $95 \%$ \\
\hline Downturns & & $92 \%$ & $89 \%$ & $95 \%$ & $94 \%$ & $90 \%$ & $100 \%$ & $94 \%$ & $92 \%$ \\
\hline Non-downturns & & $91 \%$ & $92 \%$ & $94 \%$ & $95 \%$ & $89 \%$ & $98 \%$ & $90 \%$ & $96 \%$ \\
\hline
\end{tabular}

1) The dependent variable is a binary variable taking the value of 1 in a severe downturn, defined as being during a run of quarters when GDP per

capita falls cumulatively by at least $2 \%$ points, and zero otherwise

2) Standard deviation of the explanatory variable over the full sample.

3) The unemployment gap is the OECD NAIRU measure less the unemployment rate, so a positive value indicates an over-heating labour market.

4) Predictions categorised according to a $15 \%$ probability threshold.

For the probit regression at a horizon of $\mathrm{Q}$ quarters $(\mathrm{Q}=2,4,6$ or 8) all explanatory variables enter the equations lagged by $\mathrm{Q}$ quarters except $\mathrm{OECD}$ aggregate variables which are lagged an extra quarter (because of the additional time delays in constructing the aggregate). Statistical significance of coefficients at the $1 \%, 5 \%$ and $10 \%$ levels are denoted by '***', '**' and '*', respectively.

Source: OECD Analytical Database and Bank for International Settlements. 
Table A2. Probit regressions explaining downturns in Sweden at different horizons, over a full sample and pre-GFC sample

\begin{tabular}{|c|c|c|c|c|c|c|c|c|c|}
\hline \multirow{3}{*}{$\begin{array}{l}\text { Binary dependent variable }{ }^{1} \text { : } \\
1=\text { severe downturn, } \\
0=\text { otherwise }\end{array}$} & \multicolumn{7}{|c|}{ Probit regression at horizon of $Q$ quarters } & \multirow[b]{2}{*}{$\mathrm{Q}=8$} & \multirow[b]{2}{*}{$\mathrm{Q}=8$} \\
\hline & & $\mathrm{Q}=2$ & $\mathrm{Q}=2$ & $Q=4$ & $Q=4$ & $\mathrm{Q}=6$ & $\mathrm{Q}=6$ & & \\
\hline & $\begin{array}{l}\text { Standard } \\
\text { deviation }^{2}\end{array}$ & $\begin{array}{l}\text { 1973Q4- } \\
2018 Q 3\end{array}$ & $\begin{array}{l}\text { 1973Q4- } \\
\text { 2008Q1 }\end{array}$ & $\begin{array}{l}\text { 1974Q2- } \\
2018 Q 3\end{array}$ & $\begin{array}{l}\text { 1974Q2- } \\
\text { 2008Q1 }\end{array}$ & $\begin{array}{l}1975 Q 4- \\
2018 Q 3\end{array}$ & $\begin{array}{l}\text { 1975Q4- } \\
\text { 2008Q1 }\end{array}$ & $\begin{array}{l}\text { 1976Q2- } \\
2018 Q 3\end{array}$ & $\begin{array}{l}\text { 1976Q2- } \\
\text { 2008Q1 }\end{array}$ \\
\hline Constant & & $-1.16^{* * *}$ & $-1.21^{\star \star *}$ & $-1.07^{\star \star \star}$ & $-1.83^{\star * \star}$ & $-4.58^{* \star *}$ & $-4.97^{\star * \star}$ & $-3.32^{\star \star *}$ & $-15.33^{* * *}$ \\
\hline Yield curve & 1.25 & $-1.55^{* * *}$ & $-1.19^{\star * \star}$ & $-0.98^{* * *}$ & $-1.75^{* * *}$ & $-0.44^{* * *}$ & $-0.63^{\star * \star}$ & & \\
\hline Unemployment gap ${ }^{3}$ & 1.53 & & & $0.48^{* *}$ & -0.65 & $0.43^{* * *}$ & $0.67^{*}$ & & \\
\hline \multicolumn{10}{|l|}{ Private credit-to-GDP ratio } \\
\hline 3-year annual avg change & 3.51 & & & & & & & $0.18^{* * *}$ & $0.34^{* *}$ \\
\hline \multicolumn{10}{|l|}{ Real house prices } \\
\hline 1-year annual growth & 6.86 & $-0.16^{\star \star *}$ & $-0.20^{* *}$ & & & & & & \\
\hline 3-year annual avg growth & 5.67 & $0.47^{\star \star \star}$ & $0.54^{\star \star \star}$ & $0.21^{\star \star \star}$ & $0.61^{\star \star \star}$ & & & & \\
\hline House-price-to-income ratio & 14.99 & & & & & $0.04^{* \star *}$ & $0.05^{\star \star}$ & $0.02^{*}$ & $0.16^{* \star *}$ \\
\hline \multicolumn{10}{|l|}{ OECD credit-to-GDP } \\
\hline 3-year annual avg change & 1.02 & & & & & $0.57^{\star \star *}$ & $0.85^{* \star *}$ & $0.56^{* \star *}$ & $3.16^{\star \star *}$ \\
\hline \multicolumn{10}{|l|}{$O E C D$ real house prices } \\
\hline 1-year annual growth & 3.19 & $-0.60^{\star \star \star}$ & $-0.62^{\star \star *}$ & $-0.43^{\star * *}$ & $-0.84^{* * *}$ & & & & \\
\hline 3-year annual avg growth & 2.56 & & & & & & & & \\
\hline McFadden R-sqd & & 0.69 & 0.63 & 0.65 & 0.70 & 0.43 & 0.49 & 0.41 & 0.79 \\
\hline$\%$ of correct predictions ${ }^{4}$ & & $88 \%$ & $88 \%$ & $86 \%$ & $93 \%$ & $81 \%$ & $81 \%$ & $89 \%$ & $91 \%$ \\
\hline Downturns & & $97 \%$ & $100 \%$ & $95 \%$ & $96 \%$ & $95 \%$ & $88 \%$ & $92 \%$ & $92 \%$ \\
\hline Non-downturns & & $86 \%$ & $86 \%$ & $84 \%$ & $92 \%$ & $78 \%$ & $79 \%$ & $89 \%$ & $91 \%$ \\
\hline
\end{tabular}

See notes to Table A1

Source: OECD Analytical Database and Bank for International Settlements. 
Table A3. Regressions of forecast errors for the United Kingdom on downturn probabilities, over a full sample and pre-GFC sample

\begin{tabular}{|c|c|c|c|c|c|c|}
\hline \multirow{4}{*}{$\begin{array}{l}\text { (A) United Kingdom } \\
\text { Forecast published in } \\
\text { Forecast horizon } \\
\text { Sample period }\end{array}$} & \multicolumn{6}{|c|}{ Dependent variable: forecast error, $\in \mathrm{t}(\mathrm{s}, \mathrm{t}+\mathrm{i})$} \\
\hline & Autumn & Autumn & Spring & Spring & Autumn & Autumn \\
\hline & year-ahead & year-ahead & year-ahead & year-ahead & 2-years-ahead & 2-years-ahead \\
\hline & $1980-2017$ & 1980-2007 & $1982-2017$ & $1982-2007$ & $1989-2017$ & 1989-2007 \\
\hline Intercept term, $\left(\beta_{0}\right)$ & $0.27^{*}$ & $0.35^{\star *}$ & 0.17 & $0.33^{*}$ & -0.18 & 0.02 \\
\hline Downturn probability $P_{t}^{(s, t+i)},\left(\beta_{1}\right)$ & $-3.54^{* * *}$ & $-3.30^{* * *}$ & $-4.25^{\star * *}$ & $-4.27^{\star * \star}$ & $-3.72^{\star * *}$ & $-3.43^{* * *}$ \\
\hline R-sqd adjusted & 0.53 & 0.53 & 0.47 & 0.63 & 0.28 & 0.60 \\
\hline (B) Sweden & \multicolumn{6}{|c|}{ Dependent variable: forecast error, $\epsilon \mathrm{t}(\mathrm{s}, \mathrm{t}+\mathrm{i})$} \\
\hline Forecast published in & Autumn & Autumn & Spring & Spring & Autumn & Autumn \\
\hline Forecast horizon & year-ahead & year-ahead & year-ahead & year-ahead & 2-years-ahead & 2-years-ahead \\
\hline Sample period & $1980-2017$ & $1980-2007$ & $1982-2017$ & $1982-2007$ & $1989-2017$ & $1989-2007$ \\
\hline Intercept term, $\left(\beta_{0}\right)$ & 0.07 & 0.00 & 0.11 & 0.04 & 0.32 & 0.23 \\
\hline Downturn probability $P_{t}^{(s, t+i)},\left(\beta_{1}\right)$ & $-2.13^{\star * *}$ & $-1.33^{*}$ & $-4.24^{\star * *}$ & $-3.07^{\star \star \star}$ & $-4.83^{\star * *}$ & $-3.22^{\star \star \star}$ \\
\hline R-sqd adjusted & 0.38 & 0.11 & 0.62 & 0.38 & 0.54 & 0.50 \\
\hline
\end{tabular}

Note: Statistical significance of coefficients at the $1 \%, 5 \%$ and $10 \%$ levels are denoted by ‘***’, ‘**' and '*”, respectively. 